LAWRENCE LIVERMORE NATIONAL LABORATORY

California GAMA Special Study: An isotopic and dissolved gas investigation of nitrate source and transport to a public supply well in Califonia's Central Valley

Michael J. Singleton, Jean E. Moran*, Sarah .K. Roberts, Darren J. Hillegonds and Bradley K. Esser

Lawrence Livermore National Laboratory

*California State University, East Bay

May 5, 2010

Final report for the California State Water Resources Control Board

GAMA Special Studies Task 9.2 :

Assessing Natural Attenuation of Contaminants in Deep Aquifer Systems 


\section{Disclaimer}

This document was prepared as an account of work sponsored by an agency of the United States government. Neither the United States government nor Lawrence Livermore National Security, LLC, nor any of their employees makes any warranty, expressed or implied, or assumes any legal liability or responsibility for the accuracy, completeness, or usefulness of any information, apparatus, product, or process disclosed, or represents that its use would not infringe privately owned rights. Reference herein to any specific commercial product, process, or service by trade name, trademark, manufacturer, or otherwise does not necessarily constitute or imply its endorsement, recommendation, or favoring by the United States government or Lawrence Livermore National Security, LLC. The views and opinions of authors expressed herein do not necessarily state or reflect those of the United States government or Lawrence Livermore National Security, LLC, and shall not be used for advertising or product endorsement purposes.

\section{Auspices Statement}

This work performed under the auspices of the U.S. Department of Energy by Lawrence Livermore National Laboratory under Contract DE-AC52-07NA27344. 
California GAMA Special Study: An isotopic and dissolved gas investigation of nitrate source and transport to a public supply well in Califonia's Central Valley

Michael J. Singleton, Jean E. Moran*, Sarah .K. Roberts, Darren J. Hillegonds, and Bradley K. Esser

Lawrence Livermore National Laboratory

*California State University, East Bay

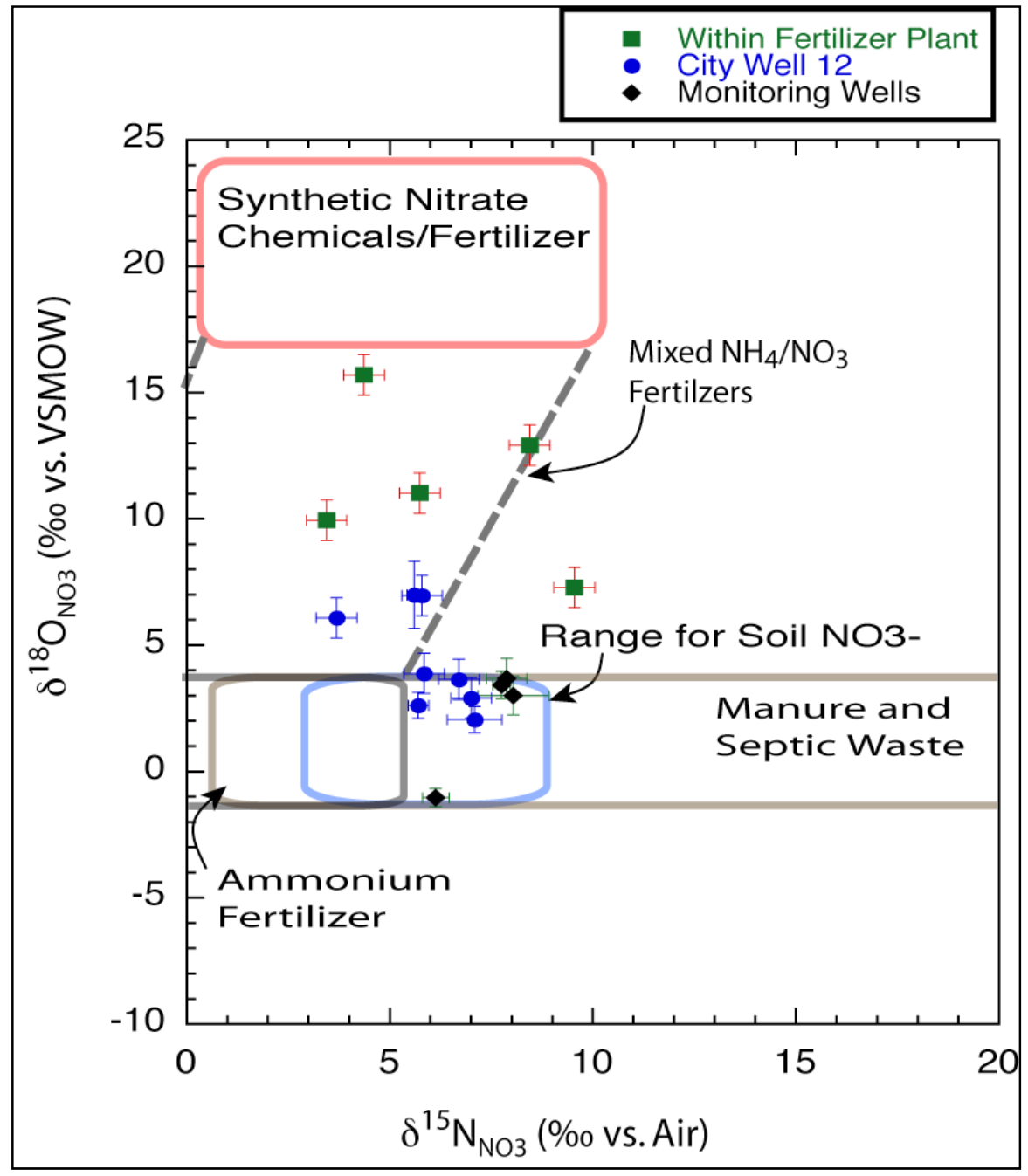

Final Report for GAMA Special Studies Task 9.2

LLNL-TR-427957

Prepared in cooperation with the California

State Water Resource Control Board 
Suggested citation:

Singleton M.J, Moran J.E, Roberts, S.R. Hillegonds, D.J., and Esser, B.K. (2010) California GAMA Special Study: An isotopic and dissolved gas investigation of nitrate source and transport to a public supply well in Califonia's Central Valley, Lawrence Livermore National Laboratory LLNL-TR-42795 


\title{
California GAMA Special Study: An isotopic and dissolved gas investigation of nitrate source and transport to a public supply well in Califonia's Central Valley
}

\author{
By Michael J. Singleton, Jean E. Moran*, Bradley K. Esser, Sarah .K. Roberts, and \\ Darren J. Hillegonds
}

Lawrence Livermore National Laboratory, *California State University, East Bay

Prepared in cooperation with the California State Water Resource Control Board

\section{Executive Summary}

This study investigates nitrate contamination of a deep municipal drinking water production well in Ripon, CA to demonstrate the utility of natural groundwater tracers in constraining the sources and transport of nitrate to deep aquifers in the Central Valley. The goal of the study was to investigate the origin (source) of elevated nitrate and the potential for the deep aquifer to attenuate anthropogenic nitrate. The site is ideal for such an investigation. The production well is screened from 165-325 feet below ground surface and a number of nearby shallow and deep monitoring wells were available for sampling. Furthermore, potential sources of nitrate contamination to the well had been identified, including a fertilizer supply plant located approximately 1000 feet to the east and local almond groves. A variety of natural isotopic and dissolved gas tracers including ${ }^{3} \mathrm{H}-{ }^{3} \mathrm{He}$ groundwater age and the isotopic composition of nitrate are applied to identify nitrate sources and to characterize nitrate transport. An advanced method for sampling production wells is employed to help identify contaminant contributions from specific screen intervals.

Nitrate transport: Groundwater nitrate at this field site is not being actively denitrified. Groundwater parameters indicate oxic conditions, the dissolved gas data shows no evidence for excess nitrogen as the result of denitrification, and nitrate- $\mathrm{N}$ and $-\mathrm{O}$ isotope compositions do not display patterns typical of denitrification.

Contaminant nitrate source: The ambient nitrate concentration in shallow groundwater at the Ripon site ( $\sim 12 \mathrm{mg} / \mathrm{L}$ as nitrate) is typical of shallow groundwaters affected by recharge from agricultural and urban areas. Nitrate concentrations in Ripon City Well 12 (50-58 mg/L as nitrate) are significantly higher than these ambient concentrations, indicating an additional source of anthropogenic nitrate is affecting groundwater in the capture zone of this municipal drinking water well. This study provides two new pieces of evidence that the Ripon Farm Services Plant is the source of elevated nitrate in Ripon City Well 12.

1) Chemical mass balance calculations using nitrate concentration, nitrate isotopic composition, and initial tritium activity all indicate that that the source water for elevated nitrate to Ripon City Well 12 is a very small component of the water produced by City Well 12 and thus must have extremely high nitrate concentration. The high source water nitrate concentration ( $1500 \mathrm{mg} / \mathrm{L}$ as nitrate) required by these mass balance calculations precludes common sources of nitrate such as irrigated agriculture, dairy wastewater, and septic discharge. Shallow groundwater under the Ripon Farm 
Services RFS plant does contain extremely high concentrations of nitrate (>1700 mg/L as nitrate).

2) Nitrogen and oxygen isotope compositions of nitrate indicate that the additional anthropogenic nitrate source to Ripon City Well 12 is significantly enriched in $\delta^{18} \mathrm{O}-$ $\mathrm{NO}_{3}$, an isotopic signature consistent with synthetic nitrate fertilizer, and not with human or animal wastewater discharge (i.e. dairy operations, septic system discharge, or municipal wastewater discharge), or with organic fertilizer. Monitoring wells on and near the RFS plant also have high $\delta^{18} \mathrm{O}-\mathrm{NO}_{3}$, and the plant has handled and stored synthetic nitrate fertilizer that will have this isotopic signature.

The results described here highlight the complexity of attributing nitrate found in long screened, high capacity wells to specific sources. In this case, the presence of a very high concentration source near the well site combined with sampling using multiple isotopic tracer techniques and specialized depth-specific techniques allowed fingerprinting of the source in the mixed-age samples drawn from the production well.

\section{Introduction}

Water purveyors in California's Central Valley are relying more on deeper sources of groundwater in order to meet demand. Deep groundwater (below major confining units; or $>150-200 \mathrm{ft}$ bgs) typically contains lower concentrations of nitrate and other contaminants than shallow groundwater. Anthropogenic compounds, however, are being detected at greater depths in many groundwater basins. The fate of these compounds will depend on geochemical processes occurring in the deep aquifers. In this study, a deep production well that has been impacted by elevated levels of nitrate is characterized using isotopic and noble gas tracers of age and nitrate source. The goal of the study is to determine the origin of the elevated nitrate, and to determine the potential for the deep aquifer to attenuate near surface contaminants.

\section{Study Site}

A municipal drinking water production well, an industrial production well, and eight monitoring wells near the city of Ripon, California (Figure 1) were sampled in 2008 (sample dates and well information listed in Table 1) to investigate nitrate sources and transport in a drinking water aquifer. The study site is located in San Joaquin County just north of the lower Stanislaus River. With respect to groundwater, the site is in the Eastern San Joaquin Groundwater subbasin (DWR 5.22.01) within the San Joaquin River Valley Basin (DWR 5.22), which is a part of the San Joaquin River Hydrologic Region (California Department of Water Resources, 2003). 


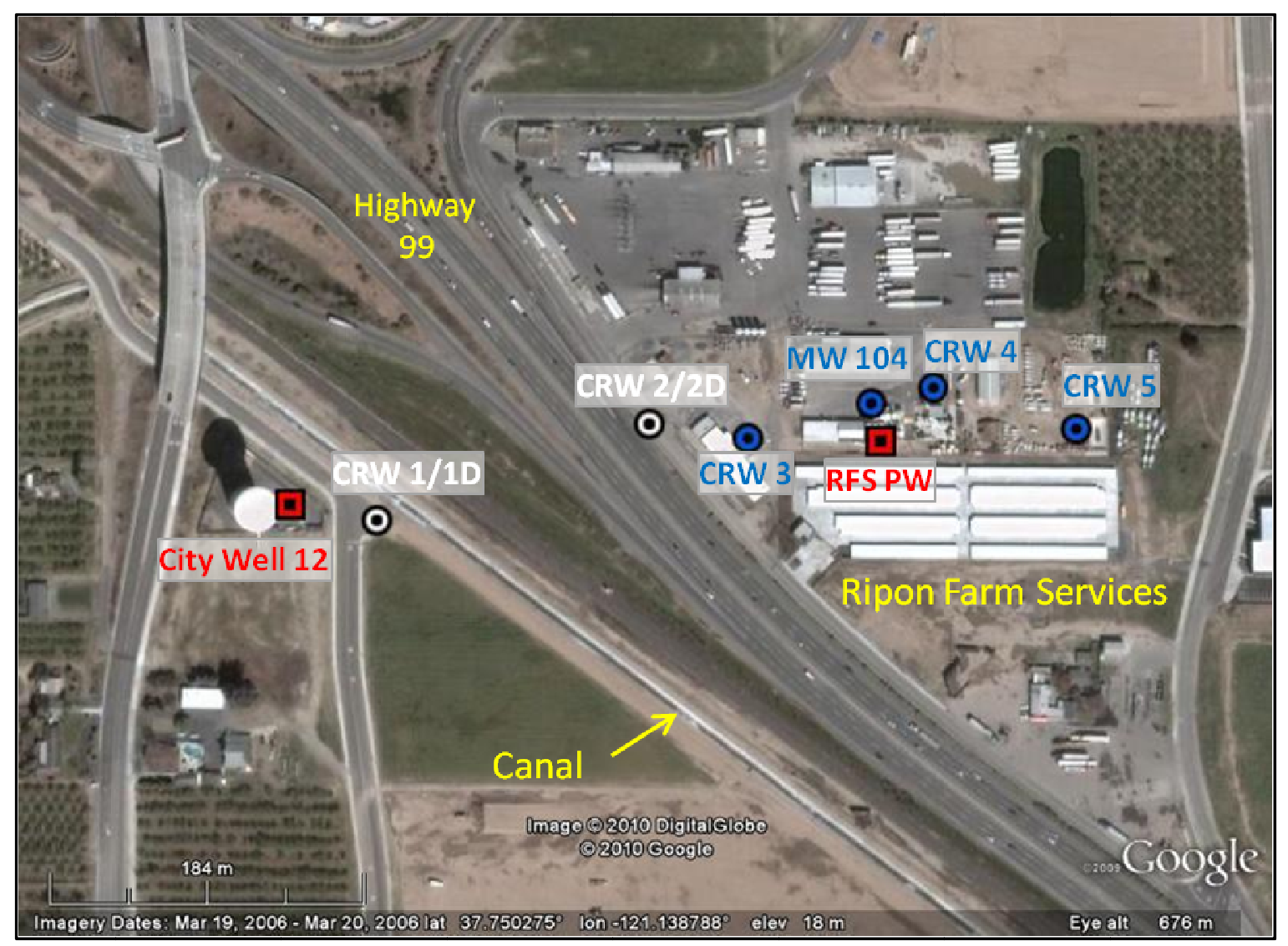

Figure 1. Wells sampled at Ripon, CA. Productions wells (Ripon City Well 12 labeled "Well 2" and Ripon Farm Services Production Well labeled "RFS PW") are indicated by red squares; shallow monitor wells (CRW-3, CRW-4, CRW-5, and MW-104) are indicated by blue circles; and shallow and deep monitor well clusters (CRW-1 and -1D; CRW-2 and -2D) are shown as white circles. Screen intervals are listed in Table 1.

Initial well sampling took place on September 8, 2008 and was completed in cooperation with Source Group International (SGI) and Blaine Tech Services. SGI was carrying out an investigation of nitrate sources to Ripon City Well 12 and provided LLNL with access to samples and background information. Blaine Tech Services collected field parameters using a YSI multimeter, and also carried out the purging and pumping of monitoring wells using a Watera inertial pump. LLNL collected samples for isotopic and dissolved gas analyses, including stable isotopic compositions of water and nitrate, concentrations of dissolved noble gases and molecular nitrogen, tritium activity, and helium isotopic composition.

Three sets of wells were sampled in the September 8, 2008 sampling event (see Table 1):

1) The City of Ripon production well “City Well 12”. City Well 12 is completed to 330 feet below ground surface (bgs), and has four screens between 165 and 326 feet bgs (at 165-195, 220-240, 268-288, and 306-326 ft bgs). Nitrate in this well is above the drinking water MCL, and consequently the well is not currently active. Preparation of the well for groundwater sampling and supplemental multilevel sampling are described below. 
2) A production well and four monitoring wells on the RFS plant. The RFS plant manufactures and distributes various fertilizers containing nitrate, ammonium and other chemicals. The RFS plant is located on the east side of California State Highway 99 directly across from Ripon City Well 12, and is considered a possible source of nitrate to City Well 12. The RFS production well is screened between 175 and 195 feet bgs. The four monitoring wells on the site (MW-104, CRW-3, CRW-4, and CRW-5) are shallow; MW-104 is screened between 20 and 40 feet bgs, while the three CRW wells are screened between 29 and 39 feet bgs.

3) Two shallow and two deep monitoring wells between the Ripon municipal well and the RFS plant, including two shallow wells screened between 25 and 35 feet bgs(CRW-1 and CRW-2) and two deep wells screened deeper than 150 feet bgs (CRW-1D at 165$185 \mathrm{ft}$ bgs, and CRW-2D at 150-170 ft bgs).

\section{SAMPLING OF PRODUCTION WELL 12}

Ripon City Well 12 was sampled on four occasions. Bulk sampling (as described above) took place on September 8 (along with monitoring well sampling), September 18, and September 29, 2008. Multi-level sampling took place on October 7 and 8, 2008.

Ripon City Well 12 is completed to 330 feet below ground surface (bgs), and has screened intervals at 165-190, 220-240, 268-288 and 306-326 feet bgs. Prior to sampling, the well was inactive. To allow collection of representative groundwater samples, pumping at City Well 12 was re-started on September 8, 2008, and continued for several weeks in order to establish steady-state flow conditions to the well before flow logging and multilevel sampling were carried out. Purged water from the well was diverted to an adjacent, lined irrigation canal that runs approximately parallel with Highway 99. Samples were collected by SGI from the well on the initiation of pumping on September 8, 2008, and follow-up samples were collected by SGI on September 18 and 29, 2008. SGI and BESST, Inc. flow logged the well and collected multilevel samples on October 7 and 8, 2008.

The October multi-level sampling of Ripon City Well 12 used a technology that allows collection of samples at discrete depth intervals during normal pumping of a high capacity drinking water well. A vertical profile of dynamic flow contribution was also obtained, using an inert dye tracer that was injected and monitored at various depths. The method was developed by the USGS (Izbicki et al., 1999) and has been licensed by BESST, Inc. (http://www.besstinc.com/dye tracer.html). The combination of flow profiling and multi-level sampling provides information that can reveal the percent contribution to total flow at various depths, the vertical pattern in hydraulic properties of aquifers, and the intervals over which contaminants and poor quality water enter the well (Gossell et al., 1999; Izbicki et al., 1999; Izbicki et al., 2005; Landon et al., 2009; Tsang et al., 1990).

The goal of the depth-discrete sampling at Well 12 was to examine the vertical profiles of nitrate and related constituents and to potentially identify a zone or zones where groundwater 
with high nitrate enters the well. Because of the large capture zone and large volume of water produced by long-screened high capacity wells, contaminants that enter the well over a discrete hydrostratigraphic interval may be strongly diluted by water drawn in over all intervals and from all directions, making it difficult to determine the nature of the contaminant source.

As implemented by personnel from BESST, Inc., a small diameter gas displacement pump is threaded along the well casing while pumping continues. In the case of Well 12, the main pump is set near the top of the uppermost screened interval so flow in the borehole is upward at all open intervals. A sample is collected from the top of the deepest screened interval (306'-326'), then the small diameter pump is raised and a sample is collected from the second deepest interval, and so on. Average incremental concentrations over each interval are determined from cumulative concentrations and flow rates for each interval by assuming simple, conservative mixing in the borehole. A linear mixing relationship is applied between vertically-paired, consecutive samples from the borehole to get incremental concentrations at four discrete intervals (165-195, 220-240, 268-288, and 306'-326').

\section{SAMPLE ANALYSIS}

LLNL analyzed samples for stable isotopic composition of $\mathrm{O}$ and $\mathrm{H}$ in water, stable isotopic composition of $\mathrm{N}$ and $\mathrm{O}$ isotopes in nitrate, excess $\mathrm{N}_{2}$, C isotopes in DIC, tritium and noble gases using methods describe in the "References for Analytical Methods Used in This Study" section at the end of this report. Data for all analyses are provided in Tables 1-4.

\section{Results and Discussion}

\section{LACK OF EVIDENCE FOR DENITRIFICATION}

Groundwaters characterized in this study have measureable nitrate, high oxidation-reduction potentials (ORPs), and moderate dissolved oxygen (DO) concentrations (Table 1). Nitrate is stable in oxic groundwaters such as these; denitrification generally requires much more reducing conditions. A number of samples from this study, nevertheless, had high dissolved $\mathrm{N}_{2} / \mathrm{Ar}$ ratios (Table 4; 9 samples with $\mathrm{N}_{2} / \mathrm{Ar}>45$ ), which would normally indicate excess dissolved nitrogen gas as a result of saturated zone denitrification. However, the high $\mathrm{N}_{2} / \mathrm{Ar}$ ratios observed here are negatively correlated with Ar concentrations (Figure 2), which is consistent with gas loss rather than denitrification. When dissolved gases encounter bubbles in the water, Ar partitions into the gas phase preferentially over $\mathrm{N}_{2}$, resulting in high $\mathrm{N}_{2} / \mathrm{Ar}$ ratios and low Ar concentrations. Such degassing can take place during sampling, and we suspect that preferential argon loss did take place during inertial pumping of the monitoring wells and depth-specific sampling of the production well.

The nitrate isotopic composition data also do not support denitrification. Denitrification along a flow path generally produces a 2:1 correlation between $\delta^{15} \mathrm{~N}_{-} \mathrm{NO}_{3}$ and $\delta^{18} \mathrm{O}-\mathrm{NO}_{3}$, and an inverse correlation between "residual” nitrate and enrichment in both $\delta^{15} \mathrm{~N}-\mathrm{NO}_{3}$ and $\delta^{18} \mathrm{O}-\mathrm{NO}_{3}$. 
Neither pattern is observed in this dataset (Figure 3, Table 2), consistent with a lack of significant saturated zone denitrification.

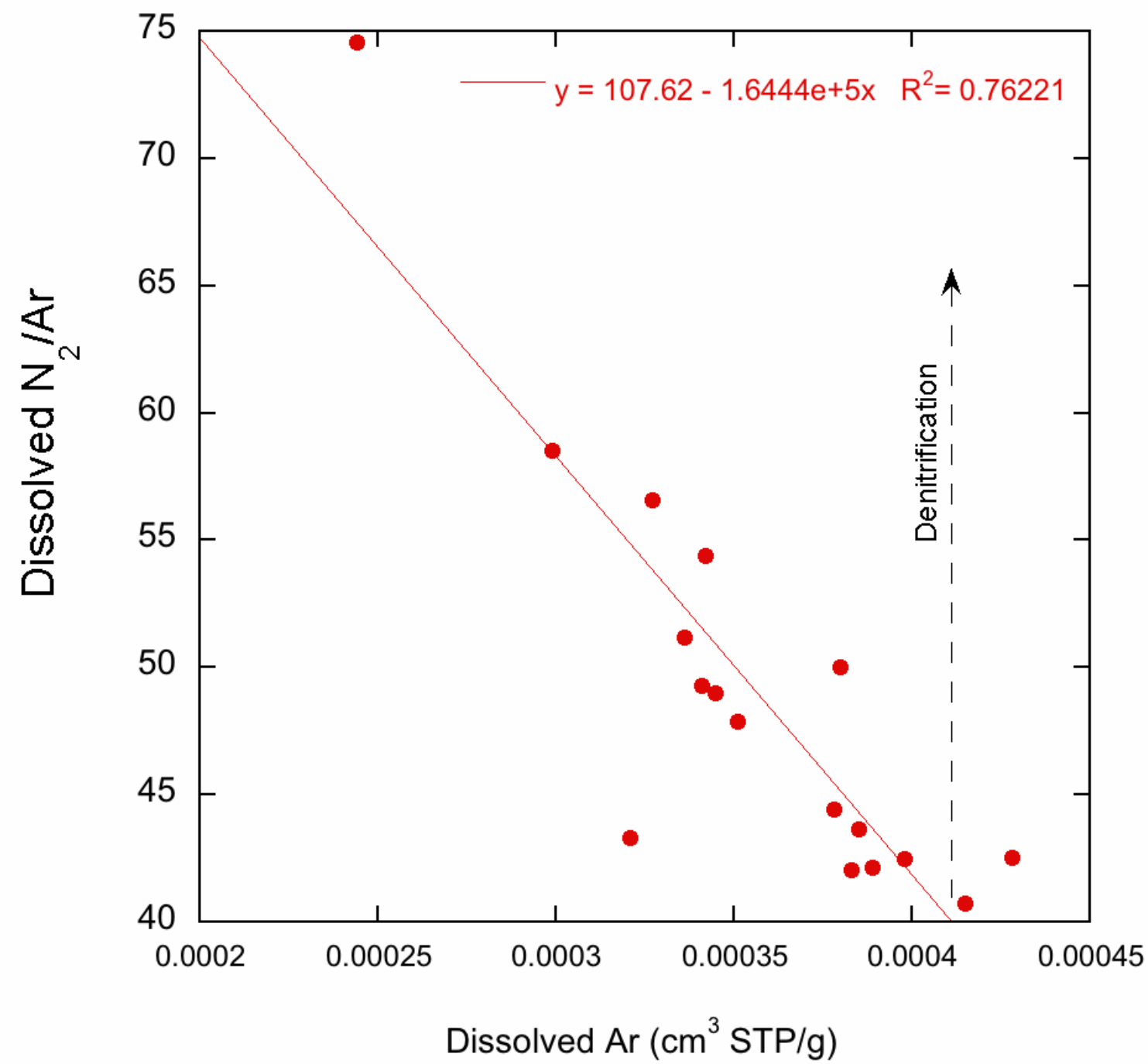

Figure 2. Dissolved $\mathrm{N}_{2} / \mathrm{Ar}$ ratios and Ar concentrations in Ripon groundwaters. The negative correlation between $\mathrm{N}_{2} / \mathrm{Ar}$ and Ar concentration suggests that degassing rather than denitrification is causing the high $\mathrm{N}_{2} /$ Ar ratios.

\section{NitRATE SOURCES - STABLE ISOTOPES OF NITRATE}

Stable isotope composition data for nitrogen and oxygen in nitrate are tabulated in Table 2 and Figures 3 and 4. On Figure 3, the groundwater nitrate isotopic compositions are plotted against nitrate source fields based on literature data (Kendall, 1998) and the measured $\delta^{18} \mathrm{O}-\mathrm{H}_{2} \mathrm{O}$ in local site groundwaters. In general, the oxygen isotope composition of nitrate $\left(\delta^{18} \mathrm{O}-\mathrm{NO}_{3}\right)$ produced by nitrification of ammonium is correlated with the oxygen isotope composition of ambient water $\left(\delta^{18} \mathrm{O}-\mathrm{H}_{2} \mathrm{O}\right)$. This correlation is due to incorporation of local water and 
atmospheric oxygen, typically in a 2:1 ratio, during production of nitrate from ammonium. Atmospheric oxygen has a nearly constant $\delta^{18} \mathrm{O}$ value of $23.5 \%$, but the oxygen isotope composition of water is variable. For this reason, it is necessary to calculate the expected ranges of nitrate $\delta^{18} \mathrm{O}$ values $\left(\delta^{18} \mathrm{O}-\mathrm{NO}_{3}\right)$ based on measurements of local water $\delta^{18} \mathrm{O}$ values $\left(\delta^{18} \mathrm{O}-\mathrm{H}_{2} \mathrm{O}\right)$ for sources where nitrification of ammonium is an important process in the production of nitrate. These sources may include nitrate produced in the soil zone, nitrate from nitrification of ammonium fertilizers, and nitrate from ammonium wastes such as septic systems or manure. Sources of manufactured nitrate, including fertilizers, contain oxygen derived solely from the atmosphere, and are therefore readily distinguished from the other nitrified sources such as plant-derived $\mathrm{N}$ or animal waste. However, mixed sources such as ammonium-nitrate fertilizers will have $\delta^{18} \mathrm{O}-\mathrm{NO}_{3}$ values that fall between atmospheric oxygen and locally nitrified sources since the ammonium component is converted to nitrate in the presence of local water.

The ranges of $\delta^{18} \mathrm{O}-\mathrm{NO}_{3}$ for nitrified sources shown in Figure 3 and Figure 4 were calculated based on the measured $\delta^{18} \mathrm{O}-\mathrm{H}_{2} \mathrm{O}$ values at Ripon wells. The range was calculated assuming a 2:1 ratio of local water and atmospheric oxygen is imparted to the nitrate during nitrification. Local water $\delta^{18} \mathrm{O}-\mathrm{H}_{2} \mathrm{O}$ values within $+/-3$ standard deviations from the mean $\delta^{18} \mathrm{O}-\mathrm{H}_{2} \mathrm{O}$ value were used to calculate the range of likely $\delta^{18} \mathrm{O}-\mathrm{NO}_{3}$ values.

The isotopic composition of nitrogen and oxygen in nitrate from the Ripon field study area is divided into three groups: wells within the RFS plant, City Well 12, and monitoring wells. Nitrate from wells within the RFS plant has $\delta^{15} \mathrm{~N}-\mathrm{NO}_{3}$ values of 3.5 to $9.6 \%$, and $\delta^{18} \mathrm{O}-\mathrm{NO}_{3}$ values of 7.3 to $15.7 \%$. Except for the sample of CRW-3 (N: 9.6\%o, O: 7.3\%o), these values fall within the range expected for nitrate derived from synthetic ammonium nitrate fertilizers. Well CRW-3 has a high $\delta^{18} \mathrm{O}-\mathrm{NO}_{3}$ value consistent with an ammonium nitrate source, but has a slightly higher $\delta^{15} \mathrm{~N}-\mathrm{NO}_{3}$ value, which may be due to mixing with other sources of nitrate. All of the wells sampled within the RFS plant have $\delta^{18} \mathrm{O}-\mathrm{NO}_{3}$ values that are above the range expected for likely sources of natural nitrate.

Samples from City Well 12 have $\delta^{15} \mathrm{~N}-\mathrm{NO}_{3}$ values of 3.7 to $7.1 \%$ and $\delta^{18} \mathrm{O}-\mathrm{NO}_{3}$ values from 2.1 to $7.0 \%$ o. Composite samples collected from a wellhead sample port on City Well 12 fall within the range of isotopic compositions expected for nitrate formed in the soil or from nitrate derived from septic systems or manure. Three samples that were collected at depth-specific intervals (220-240', 268-288', and 306-326') in City Well 12 had $\delta^{18} \mathrm{O}^{\prime} \mathrm{NO}_{3}$ values that are higher than would be expected without the addition of synthetic nitrate, such as ammonium nitrate fertilizer. The shallowest sample collected from City Well 12 (165-195') had an isotopic composition similar to composite samples from the well.

The enriched $\delta^{18} \mathrm{O}-\mathrm{NO}_{3}$ values for nitrate observed in wells within the RFS plant and the three lower intervals of Well 12 are indicative of an inorganic fertilizer as a nitrate source. Such $\delta^{18} \mathrm{O}-\mathrm{NO}_{3}$ values are infrequently observed in groundwater, even though inorganic fertilizer nitrate is a major, widespread source of nitrate to groundwater. The ammonium nitrate fertilizer source signature may be preserved at the Ripon site because the nitrate was not taken up by 
plants or re-mineralized in the soil zone, but rather passed directly from the source to the saturated zone (Mengis et al., 2001).

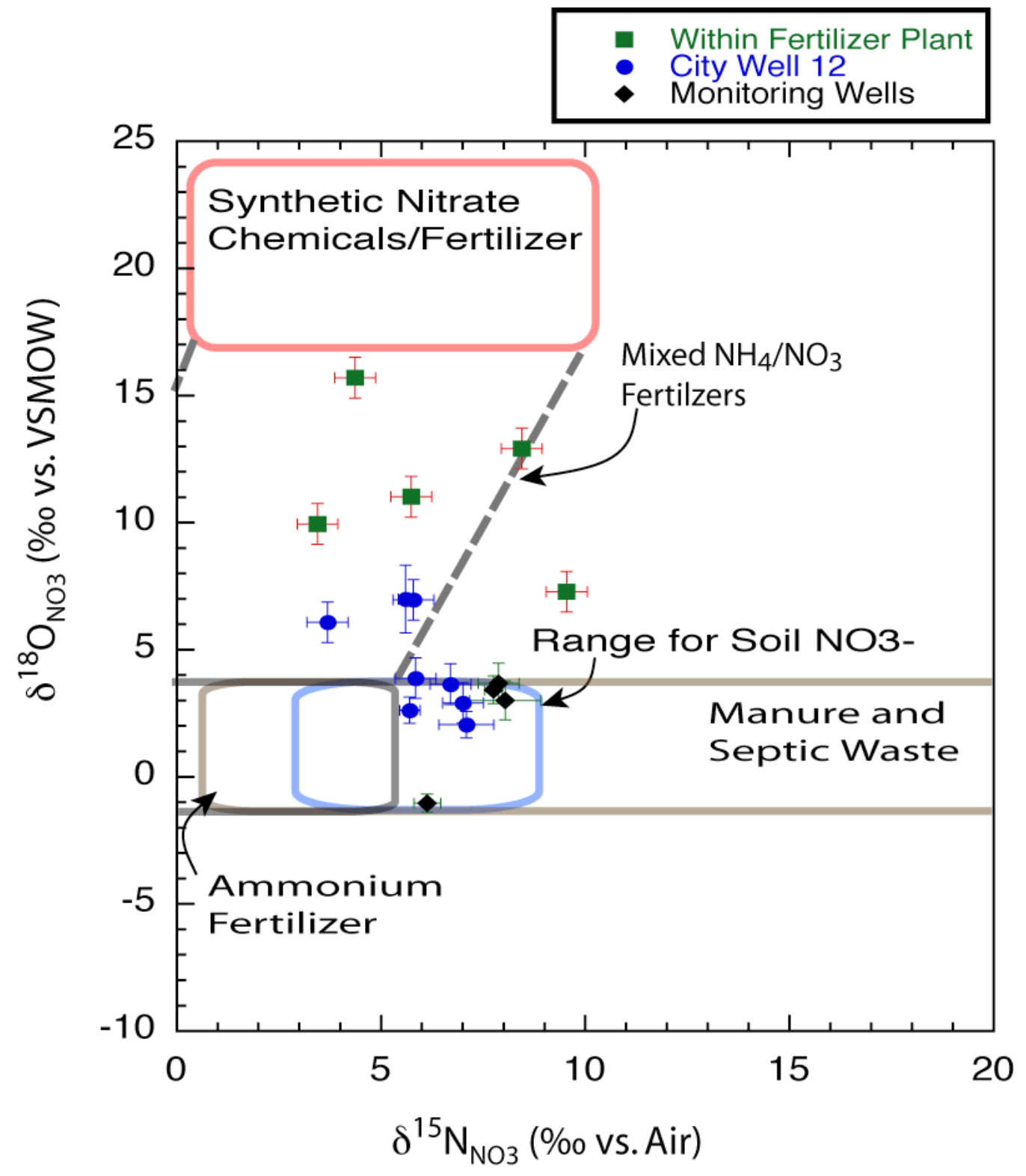

Figure 3. Nitrogen and oxygen isotope compositions of dissolved nitrate in wells sampled at Ripon, CA. Observed ranges from nitrate sources are modified from Kendall (1998)based on the observed range of oxygen isotope composition of water from this study (see text). 


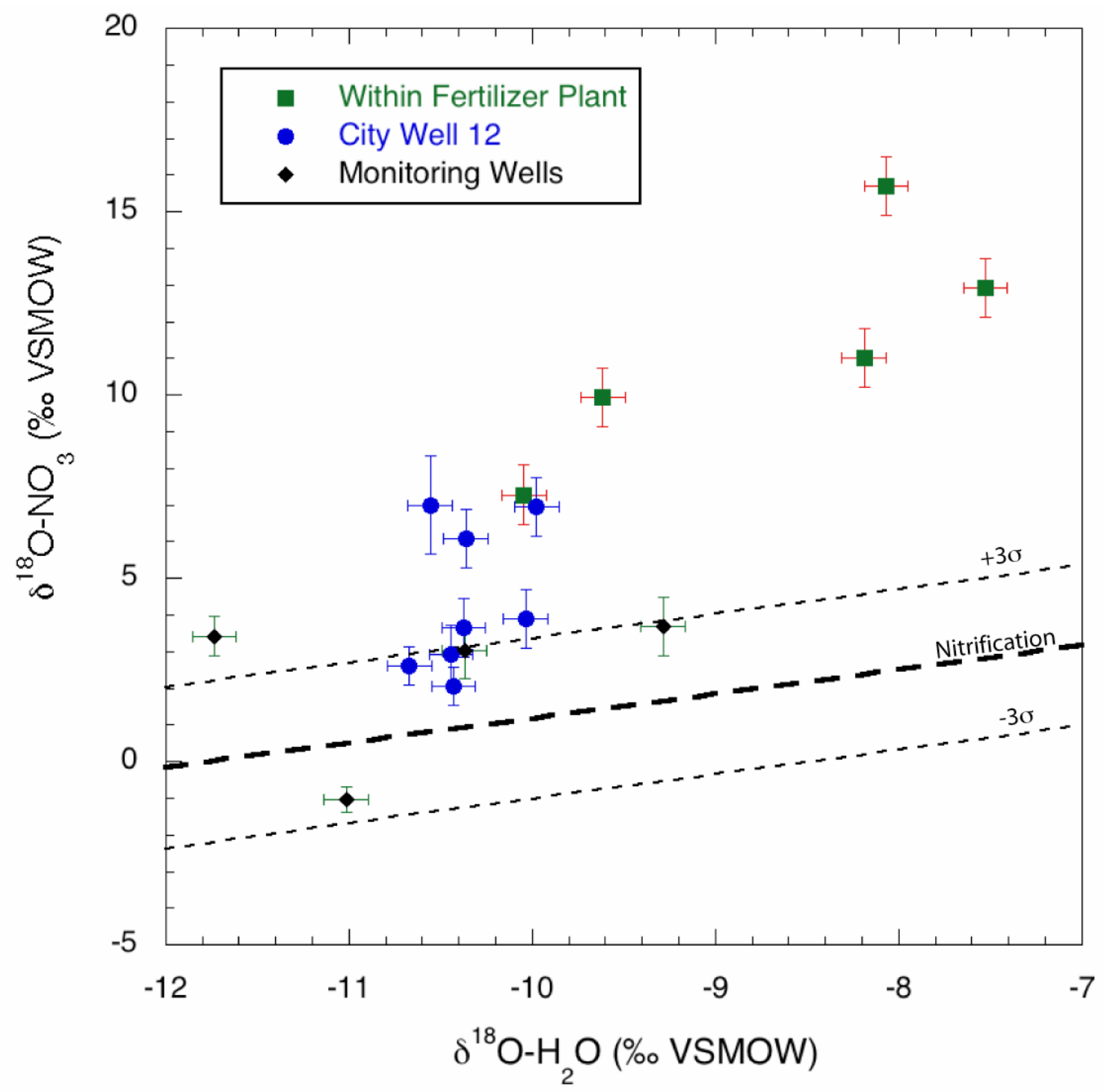

Figure 4. The oxygen isotope composition of nitrate and water for wells sampled in this study. Lines are shown for the predicted $\delta^{18} \mathrm{O}-\mathrm{NO}_{3}$ values for nitrification in the presence of local waters, based on the assumption of a 2:1 ratio of water- $\mathrm{O}$ and atmospheric-O during nitrification. Ranges are shown for $+/-3$ standard deviations in the $\delta^{18} \mathrm{O}-\mathrm{H}_{2} \mathrm{O}$ values measured at this site. Samples that plot above these lines likely contain nitrate from a manufactured source.

Monitoring wells located near City Well 12 (CRW-1 and CRW-1D) and just outside of the RFS plant (CRW-2 and CRW-2D) have $\delta^{15} \mathrm{~N}_{-} \mathrm{NO}_{3}$ values of 6.1 to $8.0 \%$ and $\delta^{18} \mathrm{O}-\mathrm{NO}_{3}$ values from -1.0 to $3.7 \%$. All of these wells are within the range of isotopic compositions expected for nitrate formed in the soil or from nitrate derived from septic systems or manure. The low $\delta^{18} \mathrm{O}-$ $\mathrm{NO}_{3}$ value of CRW-1 likely reflects nitrification in the presence of the low $\delta^{18} \mathrm{O}-\mathrm{H}_{2} \mathrm{O}$ water from the Stanislaus River and its associated irrigation canals. As a group, these samples are a likely end member for the isotopic composition of background nitrate. 


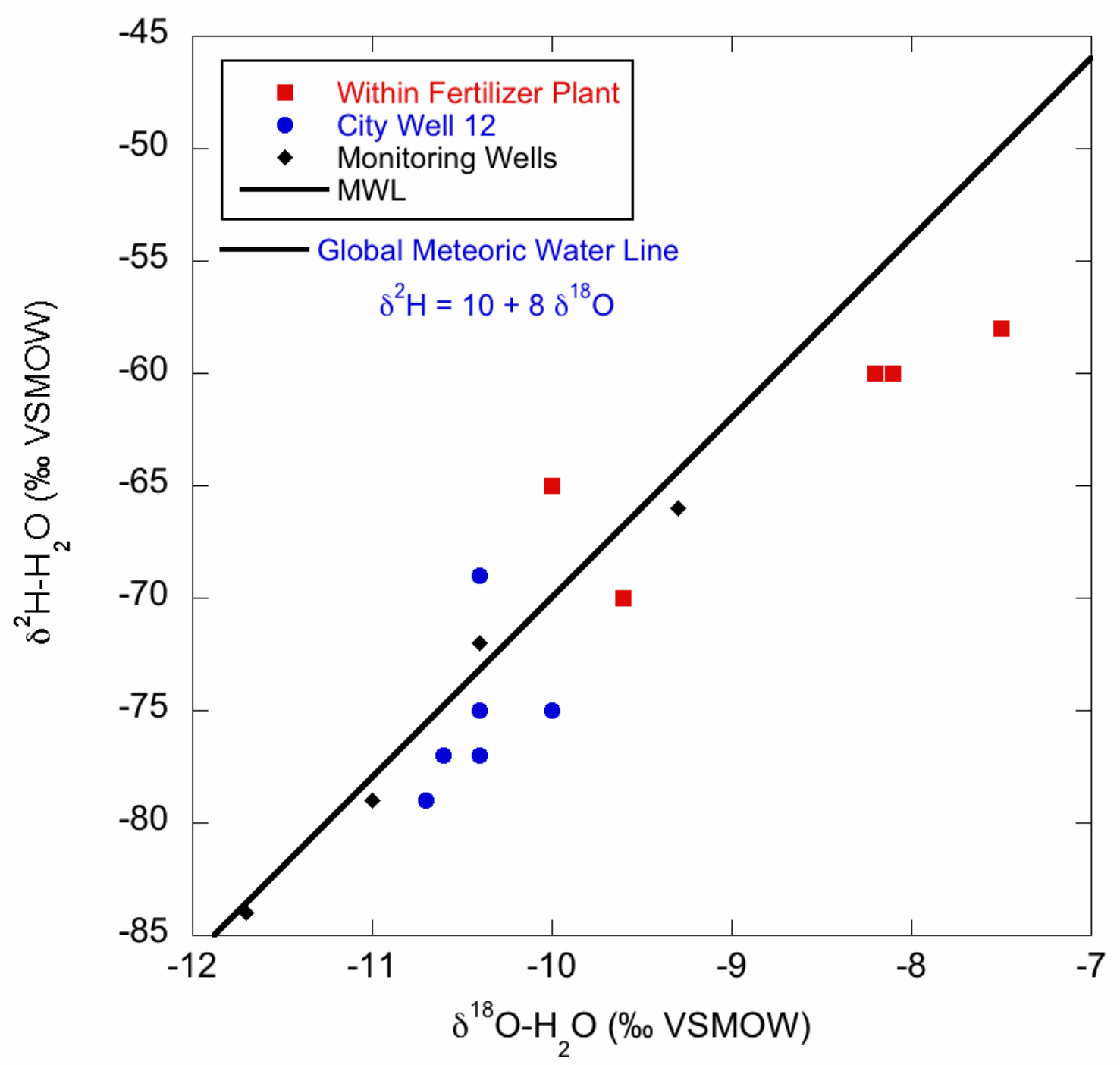

Figure 5. Stable isotope compositions of oxygen and hydrogen from waters collected for this study.

\section{WATER SOURCE - STABLE ISOTOPES OF WATER}

The influence of low $\delta^{18} \mathrm{O}-\mathrm{H}_{2} \mathrm{O}$ imported water from the Stanislaus River on the local aquifer is evident from the oxygen isotope data for water (Table 2, Figure 5). Groundwater recharged from local precipitation is likely to have $\delta^{18} \mathrm{O}-\mathrm{H}_{2} \mathrm{O}$ values around $-8 \%$. The Stanislaus River, which drains from the Sierra Nevada Mountains, has $\delta^{18} \mathrm{O}-\mathrm{H}_{2} \mathrm{O}$ values of less than $-10 \%$, typical for a high elevation watershed (Kendall and Coplen, 2001). Values lower than -10\%o are observed in the Ripon City Well 12, CRW-1, CRW-1D, CRW-2D, and CRW-3. The City Well site is located approximately 1.8 miles north of the Stanislaus River. It is not known whether the low $\delta^{18} \mathrm{O}-\mathrm{H}_{2} \mathrm{O}$ values reflect direct recharge from the river. There are extensive orchards near the study area that may receive irrigation canal water from the Stanislaus River, leading to recharge of the imported water in this area. Recharge ponds located approximately 1.7 miles to the south may also contribute to the presence of imported water in the aquifer. 
Pond recharge generally has a distinct evaporated isotopic signature, however, and such a signature is not observed in the production or monitoring well groundwater samples.

Shallow monitoring wells from the RFS plant have $\delta^{18} \mathrm{O}-\mathrm{H}_{2} \mathrm{O}$ of greater than -10 \%o (Figure 5), much closer to the expected value of local precipitation of -8 \%. As shown in Figure 4, the samples with the highest $\delta^{18} \mathrm{O}-\mathrm{H}_{2} \mathrm{O}$ values, closest to local water, also has high $\delta^{18} \mathrm{O}-\mathrm{NO}_{3}$ values indicative of manufactured nitrate. The high $\delta^{18} \mathrm{O}-\mathrm{H}_{2} \mathrm{O}$ waters also have the highest conductivity and nitrate concentrations. Samples with low $\delta^{18} \mathrm{O}-\mathrm{H}_{2} \mathrm{O}$ values, indicating recharge of Stanislaus River water, tend to have $\delta^{18} \mathrm{O}-\mathrm{NO}_{3}$ values that are consistent with natural sources of nitrate. As such, recharge of Stanislaus River water may act to dilute nitrate from the industrial source.

\section{GROUNDWATER AGE}

A total of 16 tritium/helium-3 age determinations were made on 9 of the 10 wells sampled at Ripon. Tritium activities, helium isotopic compositions, and noble gas concentrations are shown in Table 3. Apparent groundwater ages with propagated analytical uncertainties are shown in Table 4 and Figure 6. Note that the propagated analytical uncertainties are based on a simple piston flow model with no dispersion.

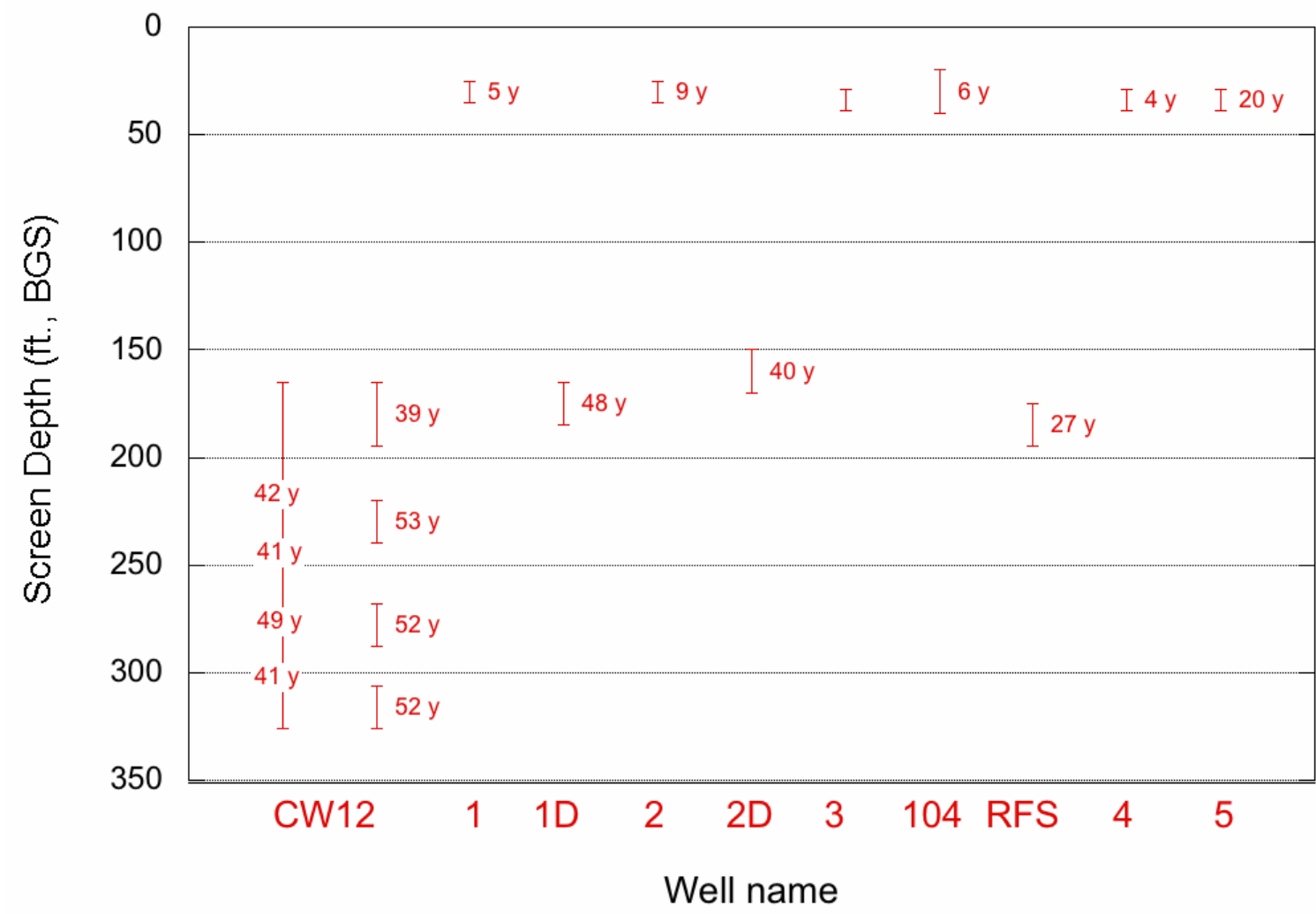

Figure 3. Screen depth and apparent age for wells sampled in this study. Wells are plotted from west to east (schematically; not to scale). The four age determinations for City Well 12 (CW12) are shown from top to bottom in order of sample date. 
A noble gas sample was not collected from well CRW-3 due to sampling issues, but its ${ }^{3} \mathrm{H}$ content $(9.3 \mathrm{pCi} / \mathrm{L})$ is similar to nearby wells with similar screen depths (CRW-2 and MW104). It was not possible to calculate recharge temperatures or excess neon $(\Delta \mathrm{Ne})$, a measure of excess air, from wells MW-104, CRW-4, CRW-5, or the Oct. 8 sample from City Well 12 due to air bubble formation during sampling. Air bubbles cause fractionation of the dissolved gas, whereby heavier gases are retained relative to lighter gases. The ${ }^{3} \mathrm{He} /{ }^{4} \mathrm{He}$ ratio is not significantly affected (Solomon et al., 1995), which allows calculation an apparent age for these samples. In the case of the monitoring wells, air bubbles were likely caused by the inertial pumping procedure. For the Oct. 8 sample from City Well 12, we speculate that air bubbles may have formed due to the depth-specific sampling procedure.

\section{Mixing BetWeEn OLD AND Young GRoundwater}

The reported tritium/helium-3 age is the mean apparent age of the portion of the sample that contains tritium above the detection limit, which generally corresponds to water recharged after 1950 (roughly the beginning of atmospheric nuclear weapons testing). Water recharging before about 1950 will not contain measurable tritium today and is referred to as "pre-modern" water. A rough estimate of the mixing ratio between "modern" water and "pre-modern" water can be determined by comparing the calculated initial ${ }^{3} \mathrm{H}$ in a groundwater sample (which is calculated by summing measured ${ }^{3} \mathrm{H}$ and tritiogenic ${ }^{3} \mathrm{He}$ ) with the ${ }^{3} \mathrm{H}$ in precipitation at the time and location of recharge. The International Atomic Energy Agency (IAEA) has operated the Global Network of Isotopes in Precipitation (GNIP) to document tritium in precipitation for several decades (International Atomic Energy Agency, 2010) (Figure 7). If one assumes 'piston flow' of groundwater, the percentage of pre-modern water is calculated by comparing the calculated initial tritium activity in the groundwater sample to IAEA precipitation tritium activity in the calculated recharge year, and assuming that the difference is due to simple binary linear mixing between tritium-containing modern water and tritium-dead pre-modern water.

The pre-modern fractions calculated in this study are subject to a number of uncertainties and should be considered semi-quantitative. We calculated initial tritium activity for local precipitation based on an exponential curve that is fit to the observed IAEA GNIP precipitation data collected from the Portland station between 1965 and 2002 (Figure 7). This curve fitting procedure results in smoothing of the IAEA GNIP precipitation data, and estimation of the fitting parameters introduces uncertainty in the final estimation of percent pre-modern. For example, Cook and Bohlke (2000) have shown that such a fitting procedure can result in overestimation of the fraction pre-modern water in a sampled groundwater for recharge during or immediately following the early 1960s peak in atmospheric nuclear weapons testing. 

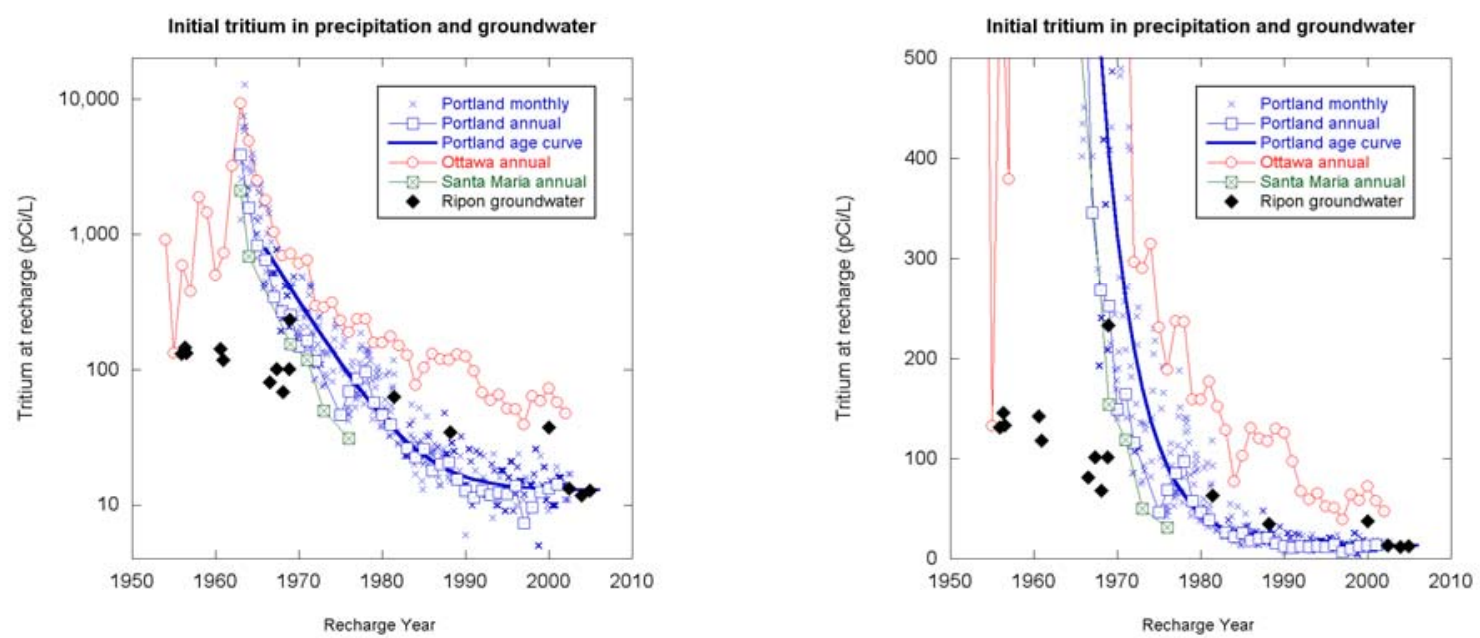

Figure 4. Atmospheric tritium observations and groundwater initial tritium activities used to determine the fraction of pre-modern water in Ripon groundwater are plotted on both logarithmic (left) and linear (right) scales. Weighted annual tritium activities in precipitation for the Ottawa (Canada), Portland (Oregon), and Santa Maria (California) sites in the IAEA Global Network of Isotopes in Precipitation (GNIP) are shown (IAEA/WMO, 2010), as is monthly data from the Portland site and the exponential fit to the Portland annual data from 1965 to 2002 that was used to calculate pre-modern fractions in Ripon groundwater. Ripon groundwater initial tritium activities from this study are plotted against vintage (recharge year as indicated by apparent age).

Figure 7 shows the annualized tritium activity data for Portland precipitation, the exponential curve fit to Portland precipitation after 1963, and the Ripon groundwater initial tritium values. Also shown for comparison in Figure 7 are precipitation data from the Santa Maria, California site (the California GNIP site with the longest and most continuous record) and from the Ottawa, Canada site (the North American GNIP site with the longest and most continuous pre1963 precipitation record).

Results for wells: At the Ripon field site, groundwaters from the shallow monitor wells contain predominantly modern water (i.e. less than $10 \%$ pre-modern water).

Groundwaters from the two deep monitor wells (CRW-1D and CRW-2D) contain large fractions of pre-modern water. Both deep groundwater monitor well samples also contain measurable tritium and must have a component of groundwater that recharged since 1950 (Table 4). The Ripon Farm Services Well is screened over the same interval as the as the deep monitor wells, and produces predominantly modern water. Three of the four composite samples from City Well 12 had apparent recharge dates between 1966 and 1968, and modeled fractions of pre-modern water of between 82 and $88 \%$. One of the composite samples (collected 09/28/2008) had an older ${ }^{3} \mathrm{H} /{ }^{3} \mathrm{He}$ age and a 1960 mean apparent recharge date. Recharge dates that are near the bomb pulse peak of 1963 have high associated uncertainty, since mixtures of water from around the peak are strongly skewed toward peak values (Schlosser et al., 1989). In depth-discrete samples of City Well 12, all screened intervals produce water with tritium concentrations that require a component of modern water. The sample from the upper screen 
had a somewhat younger age and smaller fraction pre-modern than samples from the deeper screens.

Even with the uncertainties in the estimation of pre-modern water discussed above, and the dynamic nature of the flow system around a high capacity production well, it is clear that City Well 12 produces predominantly pre-modern water, with only a small component of water recharged within the last 50 years. The fraction of modern recharge in City Well 12 is small (10-20 \%), and may be variable. The small fraction of modern water is required by the presence of tritium in all of the Well 12 samples, the ${ }^{3} \mathrm{H} /{ }^{3} \mathrm{He}$ ages of these samples, and the small amounts of tritiogenic ${ }^{3} \mathrm{He}$ relative to tritium present in precipitation during the range of apparent recharge years.

\section{SUMMARY OF TRITIUM/HELIUM-3 DATA}

Wells sampled in this study fall into three age/screen depth groups. Clear differences are observed even after taking into account the increased uncertainty in determining age and mixing ratio for samples with significant components of groundwater recharging immediately before, during or after the peak of atmospheric nuclear weapons testing.

1) Shallow monitoring wells (CRW-1, CRW-2, CRW-3, MW-104, CRW-4, and CRW-5) are screened between 20 and 40 feet BGS. These wells have apparent ages that range from 4 to 20 years with a median age of 6 years, and contain small fractions of pre-modern water $(<10 \%)$. CRW-5, located on the east side of the RFS plant, is the oldest well in this group.

2) Deep monitoring wells (CRW-1D and CRW-2D) and the RFS Production Well are screened between 150 and 185 feet BGS. Wells in this mid-depth group have apparent ages that range from 40 to 48 years. They produce water ranging from pre-dominantly modern (RFS Production Well) to predominantly pre-modern (CRW-1D) to having subequal proportions of both modern and pre-modern components (CRW-2D).

3) The deepest samples come from Ripon City Well 12, which is screened in four intervals from 165 to 326 feet BGS. City Well 12 was sampled four times at the spigot, and an additional four samples were collected at specific depth intervals corresponding to the depths of open screens in City Well 12. The four composite samples collected at the City Well 12 spigot show little variation, with apparent ages between 41 and 49 years. The shallowest sample from the depth-specific samples has an apparent age of 39 years, while samples from the bottom three depths have nearly identical ages from 52 to 53 years. Spigot samples contain $80-90 \%$ premodern water, which appears to be a smaller fraction than found in the three deeper depth intervals and a larger fraction than found in the shallowest depth interval, a pattern similar to that for groundwater age. 


\section{MiXING Model - ChOICE OF END-MEMBERS}

The simplest model for the source of water and nitrate in Ripon City Well 12 is binary mixing between a modern water component containing elevated concentrations of nitrate, and a premodern component containing "background" or ambient concentrations of nitrate. In the following sections, we argue that measured nitrate concentrations and isotopic compositions, water isotopic compositions, and groundwater ages and mixing ratios estimated from the tritium and noble gas data all support such a model.

Reasonable choices for end-members for background water and a contaminant source can be made based on measured nitrate concentrations and isotopic compositions (especially $\delta^{18} \mathrm{O}$ $\mathrm{NO}_{3}$ ) in monitoring well groundwater samples. A background concentration for nitrate was chosen based on monitoring well CRW-1, which produces groundwater with $12 \mathrm{mg} / \mathrm{L}$ nitrate (as $\mathrm{NO}_{3}$ ) . The Ripon field site is on the edge of the Ripon urban area and adjacent to land used predominantly for agriculture. The USGS National Aquifer Water Quality Assessment (NAWQA) has investigated groundwater nitrate concentrations for different land uses in representative aquifer systems across the conterminous United States. The nitrate concentration of $12 \mathrm{mg} / \mathrm{L}$ chosen as an end-member for this study site is consistent with median concentrations of nitrate in shallow groundwaters underlying agricultural land (15 mg/L) and urban land (7 mg/L) in the national NAWQA dataset (Nolan and Stoner, 2000). The Ripon site background concentration is also consistent with nitrate concentrations in groundwaters near Modesto, CA, which contain up to $17 \mathrm{mg} / \mathrm{L}$ under agricultural lands and much lower nitrate concentrations under urban areas (Burow et al., 2008). Ripon is close to Modesto ( 10 miles), and is in the same watershed and groundwater basin, with groundwaters that will be regionally affected by the same agricultural practices and hydrogeologic conditions.

The background end-member nitrate concentration chosen is significantly higher than the upper bound estimate of nitrate concentration in shallow groundwaters underlying undeveloped land (4.9 mg/L) (Nolan and Hitt, 2003), and likely includes both anthropogenic (e.g. irrigated agriculture) and non-anthropogenic regional sources of nitrate to the aquifer. Nitrate concentrations and isotopic compositions estimated for the contaminant end-member, therefore, will apply to a non-regional anthropogenic nitrate source.

The $\delta^{18} \mathrm{O}-\mathrm{NO}_{3}$ value of background nitrate $(0.9 \%$ ) was chosen based on the expected value for nitrification in the presence of water having a $\delta^{18} \mathrm{O}-\mathrm{H}_{2} \mathrm{O}$ value equal to the average of City Well 12 water $(-10.4 \%$ ) based on the principles discussed in the Nitrate Sources section of this report.

The groundwater below the Ripon Farm Services Plant was the only contaminant source characterized by samples from this study. We use monitoring well CRW-4, which is located on the RFS plant and had the highest nitrate concentration (>1700 mg/L as $\mathrm{NO}_{3}$ ) observed during the study, as an end-member for contaminant source nitrate concentration and $\delta^{18} \mathrm{O}-\mathrm{NO}_{3}$. Such high concentrations of nitrate in shallow groundwater are not typically observed in association with common sources of groundwater nitrate contamination, such as irrigated agriculture returns, field-applied dairy wastewater, or septic system discharge (Burow et al., 2008; Van Der Schans et al., 2009). 


\section{Mixing Model -Composite Calculations}

The results of mixing calculations for composite "spigot" samples from the City of Ripon production well as based on the above end-members, are listed in Table 5. If we constrain the mixing fraction of source water based on mass balance of nitrate concentrations, the average nitrate concentration in City Well 12 requires that $2.5 \%$ water in City Well 12 comes from the contaminant source.

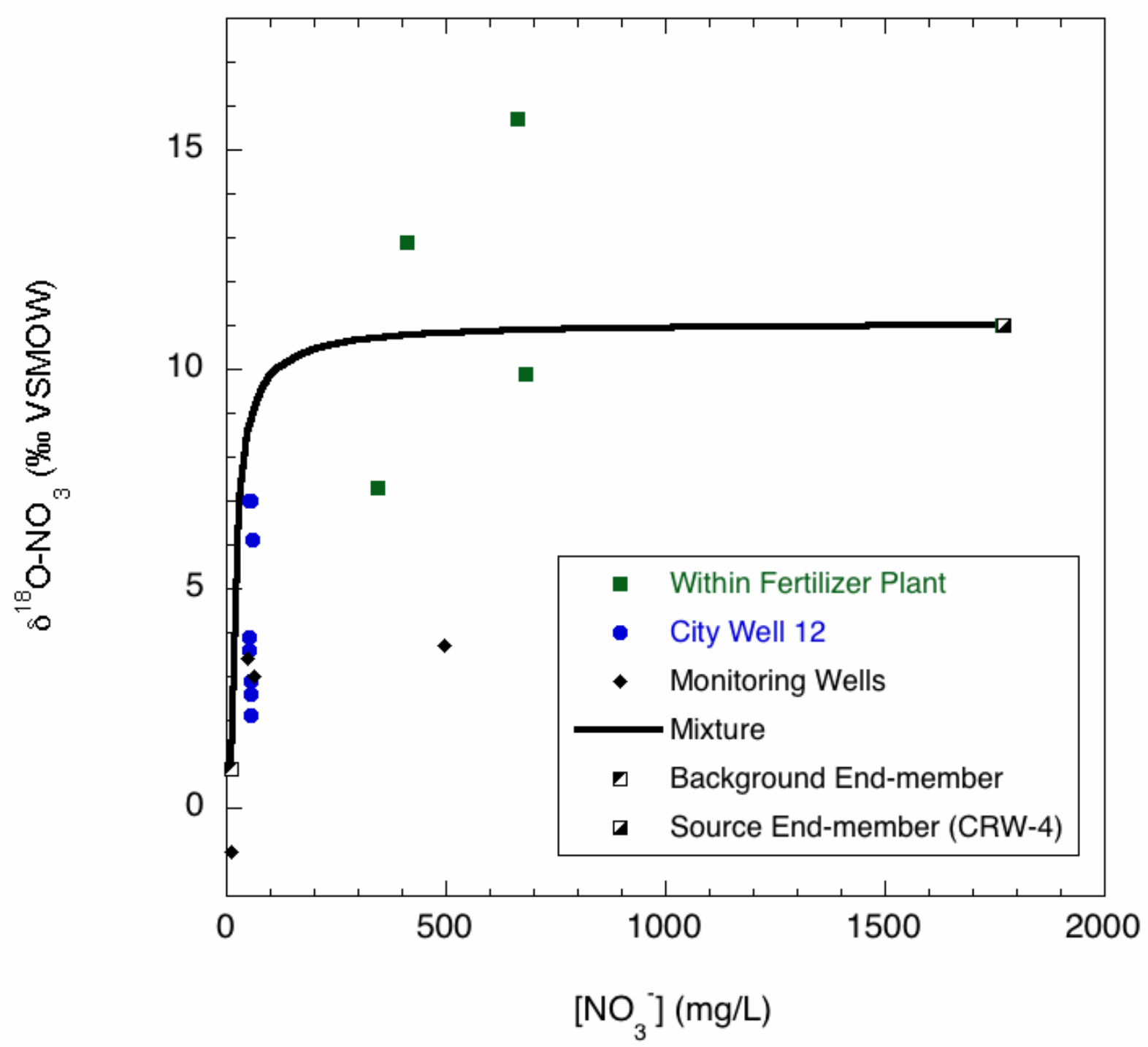

Figure 5. Mixing of nitrate concentration and oxygen isotope composition based on the end-members discussed in the text. 
Alternatively, if we use the nitrogen and oxygen isotope compositions of nitrate to constrain the mixing calculations (Figure 8), the highest $\delta^{18} \mathrm{O}-\mathrm{NO}_{3}$ value observed in City Well 12 (7 \%) requires that $1 \%$ of the water in City Well 12 come from the contaminant end-member. Varying the $\delta^{18} \mathrm{O}-\mathrm{NO}_{3}$ value of the background end-member within the values expected for nitrification at this site does not significantly change the percentage of water required from the contaminant end member. Both methods are consistent in indicating that there is a small fraction of water from a very high nitrate concentration source captured by City Well 12.

The calculated amounts of modern and pre-modern water are also consistent with these mixing calculations. The average percentage of pre-modern water in City Well 12 is 86\%, or 14\% modern water. From this fraction of modern water, we can back-calculate the minimum nitrate concentration needed to produce the observed average nitrate concentrations in City Well 12. If $14 \%$ of the water in City Well 12 came from a contaminant source, that source would need to have a nitrate concentration of at least $320 \mathrm{mg} / \mathrm{L}$ to produce the observed nitrate concentrations in the well. This assumes that all of the modern water came from the contaminant source. If in addition, some of the modern water comes from non-contaminated sources, as seems likely, then the contamination source would need to have an even higher concentration than $320 \mathrm{mg} / \mathrm{L}$. Nitrate concentrations significantly higher than this are observed in young shallow groundwater underlying the RFS plant.

\section{Mixing Model - Multi-Level CalCulations}

Another method of examining mixed sources uses the dynamic flow data and depth-specific sample results from the October 7-8, 2008 multi-level sampling of Ripon City Well 12. This approach to calculating incremental concentrations at each of the sample intervals is described in Izbicki et al. (1999; 2005) and Landon et al. (2009). The October flow data, as provided by the Source Group, are as shown below:

$\begin{array}{ccc}\begin{array}{c}\text { Top of screen } \\ \text { (ft bgs) }\end{array} & \begin{array}{c}\text { Cumulative } \\ \text { Flow } \\ \text { (gpm) }\end{array} & \begin{array}{c}\text { Incremental } \\ \text { Flow } \\ \text { (gpm) }\end{array} \\ 306 & 513 & 513 \\ 268 & 788 & 276 \\ 220 & 1,507 & 719 \\ 165 & 2,050 & 543\end{array}$

In order to determine incremental concentrations, the differences between cumulative concentrations need to be larger than the measurement errors, and in the case of Ripon City Well 12 the variations in several conservative constituents $\left(\mathrm{Cl}, \mathrm{NO}_{3}, \delta^{18} \mathrm{O}, \delta \mathrm{D}\right.$, and age over the lowest three intervals are quite small. By treating the three lower levels as one interval (using the cumulative values at 220' for flow and concentration) and the shallowest sample as another interval, the incremental values for the uppermost interval would be:

$\begin{array}{ccccccc}\text { Interval } & \begin{array}{c}\text { Incr. Flow } \\ (\mathbf{g p m})\end{array} & \begin{array}{c}\mathrm{Cl} \\ (\mathbf{m g} / \mathbf{L})\end{array} & \begin{array}{c}\mathrm{NO}_{3} \\ (\mathbf{m g} / \mathbf{L})\end{array} & \begin{array}{c}\delta^{18} \mathbf{O}-\mathbf{N O}_{3} \\ (\%)\end{array} & \begin{array}{c}\delta^{18} \mathbf{O}_{-} \mathbf{H}_{2} \mathbf{O} \\ (\%)\end{array} & \begin{array}{c}{ }^{3} \mathbf{H}-{ }^{3} \mathrm{He} \text { Age } \\ \text { (years) }\end{array} \\ \text { Lower } 3 \text { Intervals } & 1507 & 21 & 57 & 7.0 & -10.6 & 53 \\ \text { Upper Interval } & 543 & -3 & 51 & -9.5 & -11.0 & <1\end{array}$


Note: Italicized values are calculated.

These calculated incremental values are unreasonable for parameters that are expected to behave conservatively, such as $\mathrm{Cl}$ and $\delta^{18} \mathrm{O}-\mathrm{NO}_{3}$. (In the case of $\mathrm{Cl}$, a negative value is clearly unreasonable and in the case of $\delta^{18} \mathrm{O}-\mathrm{NO}_{3}$, the calculated value is too low to be in the range of any plausible nitrate source.)

Mixing proportions and calculated incremental values are very sensitive to flow values, which are not measured with a high degree of accuracy. An alternative approach is to modify flow values so that incremental groundwater parameters are reasonable for most constituents. These adjusted flow values determined from chemical mixing are not unique but are constrained by maintaining calculated flows as close as possible to values measured at the pump intake (Landon et al., 2009). If flows are adjusted to approximately match the chloride concentration in the shallowest interval with the chloride concentration in CRW-1 (4.2 mg/L), then the other parameters in the shallowest interval are calculated as follows:

\begin{tabular}{|c|c|c|c|c|c|c|}
\hline Interval & $\begin{array}{l}\text { Incr. Flow } \\
\text { (gpm) }\end{array}$ & $\begin{array}{c}\mathrm{Cl} \\
(\mathrm{mg} / \mathrm{L})\end{array}$ & $\mathrm{NO}_{3}(\mathrm{mg} / \mathrm{L})$ & $\begin{array}{c}\delta^{18} \mathrm{O}-\mathrm{NO}_{3} \\
(\% \mathrm{o})\end{array}$ & $\begin{array}{c}\delta^{18} \mathrm{O}-\mathrm{H}_{2} \mathrm{O} \\
(\% \mathrm{o})\end{array}$ & $\begin{array}{c}{ }^{3} \mathrm{H}-{ }^{3} \mathrm{He} \text { Age } \\
\text { (years) }\end{array}$ \\
\hline Lowe & 1400 & 21 & 57 & 7.0 & -10.6 & 53 \\
\hline Upper Interval & 700 & 4 & 53 & -4.5 & -10.9 & 16 \\
\hline
\end{tabular}

Note: Italicized values are calculated.

These are plausible values for most parameters in the 'unmixed' uppermost interval in Ripon City Well 12, showing that compared to the deeper intervals, the shallow interval is characterized by lower chloride concentration, slightly lower nitrate concentration, slightly lower or similar $\delta^{18} \mathrm{O}-\mathrm{H}_{2} \mathrm{O}$ composition, and significantly lower $\delta^{18} \mathrm{O}-\mathrm{NO}_{3}$.compostion. The shallower interval also produces groundwater with a greater fraction of modern groundwater and a younger ${ }^{3} \mathrm{H}-{ }^{3} \mathrm{He}$ groundwater age.

Without more extensive modeling and more accurate measurements of cumulative and incremental flow, the multi-level data are difficult to interpret. Perhaps the most useful observation to come out of the multi-level sampling, however, is that produced water from deeper screens in Ripon City Well 12 has slightly higher nitrate concentration and significantly higher $\delta^{18} \mathrm{O}-\mathrm{NO}_{3}$ than the shallowest screened interval or than bulk produced water. This observation is significant in identifying the source of additional anthropogenic nitrate to the municipal well. Given the correspondence between the $\delta^{18} \mathrm{O}-\mathrm{NO}_{3}$ signature observed in RFS wells with that observed in the lower intervals of Well 12, the inferred transport path is from an area on the RFS plant where fertilizer is released to the aquifer without being cycled through soil or plants, moving down to deeper portions of the aquifer and laterally to the lower zones captured by Well 12.

\section{Conclusions}

Sampling Methodology: Three methods were used to sample groundwater at the Ripon field site: spigot sampling of active production wells, inertial pumping (Watera) of monitoring wells, 
and multi-level sampling of the municipal production well. Neither the inertial sampling nor multi-level sampling reliably recovered samples that quantitatively retained dissolved noble gases heavier than helium. As a result, the ability to determine excess nitrogen, excess air, and recharge temperature in these samples may have been compromised. The determination of tritium and tritiogenic helium-3 was not compromised, allowing the calculation of groundwater apparent ages and mixing ratios with pre-modern water. Whether these sampling issues are intrinsic to the pumping method or are artifacts of well construction or of sample collection is not known.

Nitrate transport: Groundwater nitrate at this field site is not being actively denitrified. Groundwater parameters indicate oxic conditions, the dissolved gas data shows no evidence for excess nitrogen as the result of denitrification, and nitrate- $\mathrm{N}$ and $-\mathrm{O}$ isotopics do not display patterns typical of denitrification.

Contaminant nitrate source: The ambient nitrate concentration in shallow groundwater in the area near Ripon City Well $12\left(\sim 12 \mathrm{mg} / \mathrm{L}\right.$ nitrate as $\left.\mathrm{NO}_{3}\right)$ is typical of shallow groundwaters affected by recharge from agricultural and urban areas, i.e. groundwaters that contain both natural and anthropogenic nitrate (Nolan and Stoner, 2000). Nitrate concentrations in Ripon City Well 12 (50-58 mg/L nitrate as $\mathrm{NO}_{3}$ ) are significantly higher than these ambient concentrations, indicating that an additional source of anthropogenic nitrate is affecting groundwater in the capture zone of this municipal drinking water well. This study provides two new pieces of evidence that the Ripon Farm Services Plant is the source of elevated nitrate in Ripon City Well 12.

1) Mass balance calculations using nitrate concentration, nitrate isotopic composition, and initial tritium activity all indicate that that the source water for elevated nitrate to Ripon City Well 12 is a small component of water produced by City Well 12 and thus must have an extremely high nitrate concentration. The high source water nitrate concentration ( $1500 \mathrm{mg} / \mathrm{L}$ nitrate as $\mathrm{NO}_{3}$ ) required by these mass balance calculations precludes common sources of nitrate such as irrigated agriculture, dairy wastewater, and septic discharge. Shallow groundwater under the RFS plant does contain extremely high concentrations of nitrate $\left(>1700 \mathrm{mg} / \mathrm{L}\right.$ nitrate as $\left.\mathrm{NO}_{3}\right)$.

2) Nitrate isotopic analyses indicate that the additional anthropogenic nitrate source to Ripon City Well 12 is significantly enriched in $\delta^{18} \mathrm{O}-\mathrm{NO}_{3}$, an isotopic signature consistent with synthetic nitrate fertilizer, and not with human or animal wastewater (from dairy operations, septic system discharge, or municipal wastewater discharge), or with organic or ammonium fertilizer. Monitoring wells on the RFS plant also have high $\delta^{18} \mathrm{O}-\mathrm{NO}_{3}$ nitrate, and the site has stored synthetic nitrate fertilizer that will have this isotopic signature.

The results described here also highlight the complexity of source attribution for nitrate in long screened, high capacity production wells. Depth-specific sampling of the Ripon City Well 12 combined with the use of multiple isotopic tracer methods supports the identification of Ripon Farm Services as the source of high nitrate to the well. 
Table 1. Anions and field data for samples collected at Ripon, CA.

\begin{tabular}{|c|c|c|c|c|c|c|c|c|c|c|c|}
\hline Well & $\begin{array}{l}\text { Screen (ft. } \\
\text { BGS) }\end{array}$ & "LLNL ID & $\begin{array}{l}\text { Collection } \\
\text { Date }\end{array}$ & $\begin{array}{l}\text { Collection } \\
\text { Method }\end{array}$ & $\begin{array}{c}\mathrm{NO}_{3}^{-} \\
(\mathrm{mg} / \mathrm{L})\end{array}$ & $\begin{array}{c}\mathrm{Cl}^{-} \\
(\mathrm{mg} / \mathrm{L})\end{array}$ & $\begin{array}{c}\mathrm{SO}_{4}^{-} \\
(\mathrm{mg} / \mathrm{L})\end{array}$ & $\begin{array}{l}\text { Conductivity } \\
\text { (uS/cm) }\end{array}$ & Field pH & $\begin{array}{c}\text { Field } \\
\text { DO } \\
(\mathrm{mg} / \mathrm{L})\end{array}$ & $\begin{array}{l}\text { Field } \\
\text { ORP }\end{array}$ \\
\hline CRW-1 & $25-35$ & 106909 & $09 / 08 / 2008$ & $\begin{array}{l}\text { Inertial } \\
\text { pump }\end{array}$ & 12 & 4 & 5 & 621 & 7.90 & 2.6 & 62 \\
\hline CRW-1D & 165-185 & 106908 & 09/08/2008 & $\begin{array}{l}\text { Inertial } \\
\text { pump }\end{array}$ & 64 & 32 & 35 & 629 & 7.10 & 2.0 & 89 \\
\hline CRW-2 & $25-35$ & 106917 & $09 / 08 / 2008$ & $\begin{array}{l}\text { Inertial } \\
\text { pump }\end{array}$ & 498 & 59 & 194 & 2287 & 6.83 & 1.6 & 77 \\
\hline CRW-2D & $150-170$ & 106916 & 09/08/2008 & $\begin{array}{l}\text { Inertial } \\
\text { pump }\end{array}$ & 47 & 24 & 47 & 458 & 7.50 & 2.9 & 81 \\
\hline CRW-3 & $29-39$ & 106911 & 09/08/2008 & $\begin{array}{l}\text { Inertial } \\
\text { pump }\end{array}$ & 344 & 54 & 117 & 1801 & 6.80 & 0.6 & 106 \\
\hline CRW-4 & 29-39 & 106913 & 09/08/2008 & $\begin{array}{l}\text { Inertial } \\
\text { pump }\end{array}$ & 1766 & 191 & 529 & 6345 & 6.70 & 1.7 & 199 \\
\hline CRW-5 & 29-39 & 106914 & 09/08/2008 & $\begin{array}{l}\text { Inertial } \\
\text { pump }\end{array}$ & 681 & 52 & 210 & 2935 & 7.00 & 1.0 & 189 \\
\hline MW-104 & $20-40$ & 106912 & 09/08/2008 & $\begin{array}{l}\text { Inertial } \\
\text { pump }\end{array}$ & 413 & 92 & 144 & 2100 & 6.70 & 0.5 & 148 \\
\hline RFS Process Well & 175-195 & 106915 & 09/08/2008 & Spigot & 663 & 192 & 204 & & & & \\
\hline Ripon City Well 12 & $165-326$ & 106910 & $09 / 08 / 2008$ & Spigot & 55 & 15 & 28 & & & & \\
\hline Ripon City Well 12 & $165-326$ & 106918 & $09 / 18 / 2008$ & Spigot & 56 & 16 & 29 & & & & \\
\hline Ripon City Well 12 & $165-326$ & 106922 & $09 / 29 / 2008$ & Spigot & 54 & 16 & 27 & & & & \\
\hline Ripon City Well 12 & 165-195 & 106923 & $10 / 07 / 2008$ & Multi-level & 56 & 15 & 26 & & & & \\
\hline Ripon City Well 12 & $220-240$ & 106924 & $10 / 07 / 2008$ & Multi-level & 57 & 21 & 27 & & & & \\
\hline Ripon City Well 12 & $268-288$ & 106925 & $10 / 07 / 2008$ & Multi-level & 58 & 20 & 26 & & & & \\
\hline Ripon City Well 12 & $306-326$ & 106926 & $10 / 07 / 2008$ & Multi-level & 51 & 19 & 26 & & & & \\
\hline Ripon City Well 12 & $165-326$ & 106927 & $10 / 08 / 2008$ & Spigot & 50 & 15 & 25 & & & & \\
\hline
\end{tabular}


Table 2. Stable isotope compositions and dissolved $\mathrm{N}_{2}$ and Ar gases for samples collected at Ripon, CA.

\begin{tabular}{|c|c|c|c|c|c|c|c|c|c|c|}
\hline Well & $\begin{array}{l}\text { Screen } \\
\text { (ft. bgs) }\end{array}$ & LLNL ID & Collection & $\begin{array}{l}\text { Collection } \\
\text { Method }\end{array}$ & $\begin{array}{l}\mathrm{N}_{2}\left(\mathrm{~cm}^{3}\right. \\
\mathrm{STP} / \mathrm{g})\end{array}$ & $\begin{array}{l}\operatorname{Ar}\left(\mathrm{cm}^{3}\right. \\
\text { STP/g) }\end{array}$ & $\begin{array}{c}\delta^{18} \mathrm{O} \mathrm{H}_{2} \mathrm{O} \\
(\% o \\
\text { VSMOW) }\end{array}$ & $\begin{array}{c}\delta^{2} \mathrm{H} \mathrm{H}_{2} \mathrm{O} \\
(\%) \\
\text { VSMOW) } \\
\end{array}$ & $\begin{array}{c}\delta^{15} \mathrm{~N} \mathrm{NO}_{3} \\
\text { (\%o Air) }\end{array}$ & $\begin{array}{c}\delta^{18} \mathrm{O} \mathrm{NO}_{3}(\%) \\
\text { VSMOW) }\end{array}$ \\
\hline CRW-1 & $25-35$ & 106909 & $09 / 08 / 2008$ & $\begin{array}{l}\text { Inertial } \\
\text { pump }\end{array}$ & $1.61 \mathrm{E}-02$ & 3.83E-04 & -11.0 & -79 & $6.1 \pm 0.3$ & $-1.0 \pm 0.4$ \\
\hline CRW-1D & 165-185 & 106908 & $09 / 08 / 2008$ & $\begin{array}{l}\text { Inertial } \\
\text { pump }\end{array}$ & $1.82 \mathrm{E}-02$ & $4.28 \mathrm{E}-04$ & -10.4 & -72 & $8.0 \pm 0.9$ & $3.0 \pm 0.8$ \\
\hline CRW-2 & $25-35$ & 106917 & $09 / 08 / 2008$ & $\begin{array}{l}\text { Inertial } \\
\text { pump }\end{array}$ & 1.39E-02 & $3.21 \mathrm{E}-04$ & -9.3 & -66 & $7.9 \pm 0.5$ & $3.7 \pm 0.5$ \\
\hline CRW-2D & $150-170$ & 106916 & 09/08/2008 & $\begin{array}{l}\text { Inertial } \\
\text { pump }\end{array}$ & $1.68 \mathrm{E}-02$ & $3.85 \mathrm{E}-04$ & -11.7 & -84 & $7.8 \pm 0.2$ & $3.4 \pm 0.5$ \\
\hline CRW-3 & $29-39$ & 106911 & $09 / 08 / 2008$ & $\begin{array}{l}\text { Inertial } \\
\text { pump }\end{array}$ & $1.90 \mathrm{E}-02$ & $3.80 \mathrm{E}-04$ & -10.0 & -65 & $9.5 \pm 0.5$ & $7.3 \pm 0.5$ \\
\hline CRW-4 & $29-39$ & 106913 & $09 / 08 / 2008$ & $\begin{array}{l}\text { Inertial } \\
\text { pump }\end{array}$ & 1.86E-02 & $3.42 \mathrm{E}-04$ & -8.2 & -60 & $5.7 \pm 0.5$ & $11.0 \pm 0.5$ \\
\hline CRW-5 & $29-39$ & 106914 & 09/08/2008 & $\begin{array}{l}\text { Inertial } \\
\text { pump }\end{array}$ & $1.72 \mathrm{E}-02$ & $3.36 \mathrm{E}-04$ & -9.6 & -70 & $3.4 \pm 0.5$ & $9.9 \pm 0.5$ \\
\hline MW-104 & $20-40$ & 106912 & $09 / 08 / 2008$ & $\begin{array}{l}\text { Inertial } \\
\text { pump }\end{array}$ & 1.75E-02 & 2.99E-04 & -7.5 & -58 & $8.4 \pm 0.5$ & $12.9 \pm 0.5$ \\
\hline RFS Process Well & 175-195 & 106915 & $09 / 08 / 2008$ & Spigot & $1.82 \mathrm{E}-02$ & $2.44 \mathrm{E}-04$ & -8.1 & -60 & $4.4 \quad \pm 0.5$ & $15.7 \quad \pm 0.5$ \\
\hline Ripon City Well 12 & $165-326$ & 106910 & $09 / 08 / 2008$ & Spigot & 1.69E-02 & 3.98E-04 & -10.4 & -69 & $7.1 \pm 0.7$ & $2.1 \pm 0.5$ \\
\hline Ripon City Well 12 & $165-326$ & 106918 & $09 / 18 / 2008$ & Spigot & 1.69E-02 & 4.15E-04 & -10.4 & -75 & $7.0 \pm 0.5$ & $2.9 \pm 0.5$ \\
\hline Ripon City Well 12 & $165-326$ & 106922 & $09 / 29 / 2008$ & Spigot & $1.64 \mathrm{E}-02$ & 3.89E-04 & -10.4 & -75 & $6.7 \pm 0.5$ & $3.6 \pm 0.5$ \\
\hline Ripon City Well 12 & 165-195 & 106923 & $10 / 07 / 2008$ & Multi-level & 1.69E-02 & $3.45 \mathrm{E}-04$ & -10.7 & -79 & $5.7 \pm 0.2$ & $2.6 \pm 0.5$ \\
\hline Ripon City Well 12 & $220-240$ & 106924 & $10 / 07 / 2008$ & Multi-level & $1.68 \mathrm{E}-02$ & $3.41 \mathrm{E}-04$ & -10.6 & -77 & $5.6 \pm 0.2$ & $7.0 \pm 1.3$ \\
\hline Ripon City Well 12 & $268-288$ & 106925 & $10 / 07 / 2008$ & Multi-level & $1.68 \mathrm{E}-02$ & 3.51E-04 & -10.4 & -77 & $3.7 \pm 0.5$ & $6.1 \pm 0.5$ \\
\hline Ripon City Well 12 & $306-326$ & 106926 & $10 / 07 / 2008$ & Multi-level & 1.85E-02 & 3.27E-04 & -10.0 & -75 & $5.8 \pm 0.5$ & $7.0 \pm 0.5$ \\
\hline Ripon City Well 12 & $165-326$ & 106927 & $10 / 08 / 2008$ & Spigot & $1.68 \mathrm{E}-02$ & 3.78E-04 & -10.0 & -75 & $5.8 \pm 0.5$ & $3.9 \quad \pm 0.5$ \\
\hline
\end{tabular}


Table 3. Tritium and dissolved noble gases for samples collected at Ripon, CA.

\begin{tabular}{|c|c|c|c|c|c|c|c|c|c|c|c|}
\hline "Well Name & $\begin{array}{l}\begin{array}{l}\text { Screen } \\
\text { (ft. bgs) }\end{array}\end{array}$ & $\begin{array}{l}\text { LLNL } \\
\text { ID }\end{array}$ & "Collection & $\begin{array}{l}\text { Collection } \\
\text { Method }\end{array}$ & ${ }^{3} \mathrm{H}(\mathrm{pCi} / \mathrm{L})$ & $\begin{array}{c}{ }^{3} \mathrm{He} /{ }^{4} \mathrm{He}(1 \mathrm{e}-6 \\
\text { atom ratio) }\end{array}$ & $\begin{array}{c}{ }^{4} \mathrm{He}(1 \mathrm{e}-8 \mathrm{cc} \\
\text { STP/g) }\end{array}$ & $\begin{array}{c}\text { Ne (1e-8 cc } \\
\text { STP/g) }\end{array}$ & $\begin{array}{c}\operatorname{Ar}(1 \mathrm{e}-4 \text { cc } \\
\text { STP/g) }\end{array}$ & $\begin{array}{c}\mathrm{Kr}(1 \mathrm{e}-8 \mathrm{cc} \\
\mathrm{STP} / \mathrm{g})\end{array}$ & $\begin{array}{l}\text { Xe (1e-9 cc } \\
\text { STP/g) }\end{array}$ \\
\hline CRW-1 & $25-35$ & 106909 & 09/08/2008 & Inertial pump & $9.0 \quad \pm 0.4$ & $1.42 \pm 0.01$ & $4.65 \pm 0.09$ & $1.98 \pm 0.04$ & $3.02 \pm 0.06$ & $6.63 \pm 0.2$ & $9.24 \pm 0.28$ \\
\hline CRW-1D & $165-185$ & 106908 & 09/08/2008 & Inertial pump & $9.6 \quad \pm 0.4$ & $2.07 \pm 0.03$ & $9.67 \pm 0.19$ & $2.65 \pm 0.1$ & $3.36 \pm 0.07$ & $7.03 \pm 0.22$ & $9.50 \pm 0.28$ \\
\hline CRW-2 & $25-35$ & 106917 & 09/08/2008 & Inertial pump & $22.9 \pm 0.9$ & $1.61 \pm 0.07$ & $4.85 \pm 0.1$ & $2.06 \pm 0.04$ & $2.95 \pm 0.06$ & $6.32 \pm 0.19$ & $8.47 \pm 0.34$ \\
\hline CRW-2D & $150-170$ & 106916 & 09/08/2008 & Inertial pump & $25.0 \pm 1$ & $4.22 \pm 0.03$ & $5.72 \pm 0.11$ & $2.49 \pm 0.05$ & $3.09 \pm 0.06$ & $6.53 \pm 0.2$ & $8.78 \pm 0.27$ \\
\hline CRW-3 & $29-39$ & 106911 & 09/08/2008 & Inertial pump & $9.3 \pm 0.4$ & & & & & & \\
\hline CRW-4 & $29-39$ & 106913 & 09/08/2008 & Inertial pump & $10.3 \pm 0.4$ & $1.42 \pm 0.01$ & $4.11 \pm 0.08$ & $1.81 \pm 0.04$ & $2.74 \pm 0.05$ & $6.12 \pm 0.18$ & $9.57 \pm 0.29$ \\
\hline CRW-5 & $29-39$ & 106914 & 09/08/2008 & Inertial pump & $11.0 \pm 0.5$ & $1.73 \pm 0.07$ & $5.20 \pm 0.1$ & $2.62 \pm 0.05$ & $3.18 \pm 0.06$ & $6.67 \pm 0.2$ & $9.34 \pm 0.38$ \\
\hline MW-104 & $20-40$ & 106912 & 09/08/2008 & Inertial pump & $9.3 \pm 0.4$ & $1.48 \pm 0.02$ & $2.93 \pm 0.06$ & $1.48 \pm 0.03$ & $2.60 \pm 0.05$ & $6.07 \pm 0.18$ & $9.66 \pm 0.3$ \\
\hline RFS Process Well & 175-195 & 106915 & 09/08/2008 & Spigot & $13.7 \pm 0.6$ & $2.52 \pm 0.02$ & $3.38 \pm 0.07$ & $1.65 \pm 0.03$ & $2.71 \pm 0.05$ & $6.34 \pm 0.19$ & $10.09 \pm 0.31$ \\
\hline Ripon City Well 12 & $165-326$ & 106910 & 09/08/2008 & Spigot & $7.6 \quad \pm 0.3$ & $1.83 \pm 0.08$ & $7.25 \pm 0.14$ & $2.13 \pm 0.04$ & $3.13 \pm 0.06$ & $6.69 \pm 0.2$ & $9.31 \pm 0.38$ \\
\hline Ripon City Well 12 & $165-326$ & 106918 & 09/18/2008 & Spigot & $10.0 \quad \pm 0.4$ & $1.90 \pm 0.03$ & $7.74 \pm 0.15$ & $2.12 \pm 0.08$ & $3.13 \pm 0.06$ & $6.79 \pm 0.21$ & $9.32 \pm 0.28$ \\
\hline Ripon City Well 12 & $165-326$ & 106922 & $09 / 29 / 2008$ & Spigot & $7.3 \quad \pm 0.8$ & $1.65 \pm 0.02$ & $10.08 \pm 0.2$ & $2.10 \pm 0.08$ & $3.14 \pm 0.06$ & $6.86 \pm 0.21$ & $9.29 \pm 0.28$ \\
\hline Ripon City Well 12 & $165-195$ & 106923 & $10 / 07 / 2008$ & Multi-level & $10.8 \pm 0.5$ & $1.83 \pm 0.02$ & $8.60 \pm 0.17$ & $2.39 \pm 0.05$ & $3.17 \pm 0.06$ & $6.79 \pm 0.2$ & $9.03 \pm 0.27$ \\
\hline Ripon City Well 12 & $220-240$ & 106924 & $10 / 07 / 2008$ & Multi-level & $6.8 \pm 0.3$ & $2.02 \pm 0.02$ & $8.61 \pm 0.17$ & $2.10 \pm 0.04$ & $3.10 \pm 0.06$ & $6.67 \pm 0.2$ & $8.96 \pm 0.27$ \\
\hline Ripon City Well 12 & $268-288$ & 106925 & $10 / 07 / 2008$ & Multi-level & $7.7 \pm 0.3$ & $1.85 \pm 0.02$ & $10.20 \pm 0.2$ & $2.12 \pm 0.04$ & $3.09 \pm 0.06$ & $6.63 \pm 0.2$ & $9.45 \pm 0.28$ \\
\hline Ripon City Well 12 & $306-326$ & 106926 & $10 / 07 / 2008$ & Multi-level & $7.1 \pm 0.3$ & $1.45 \pm 0.01$ & $13.60 \pm 0.27$ & $2.50 \pm 0.05$ & $3.32 \pm 0.07$ & $7.07 \pm 0.21$ & $9.10 \pm 0.27$ \\
\hline Ripon City Well 12 & $165-326$ & 106927 & $10 / 08 / 2008$ & Spigot & $6.9 \pm 0.3$ & $1.42 \pm 0.01$ & $12.58 \pm 0.25$ & $3.56 \pm 0.07$ & $3.23 \pm 0.06$ & $6.18 \pm 0.19$ & $7.90 \pm 0.24$ \\
\hline
\end{tabular}


Table 4. Parameters calculated from tritium and dissolved gases for samples collected at Ripon, CA.

\begin{tabular}{|c|c|c|c|c|c|c|c|c|c|c|c|c|c|}
\hline "Well Name & $\begin{array}{l}\text { Screen (ft. } \\
\text { bgs) }\end{array}$ & " LLNL ID & "Collection & $\begin{array}{l}\text { Collection } \\
\text { Method }\end{array}$ & $\begin{array}{c}\text { Calculated } \\
\text { Initial }{ }^{3} \mathrm{H} \\
(\mathbf{p C i} / \mathrm{L})\end{array}$ & $\begin{array}{c}\text { Excess } \\
\text { Air (as } \\
\Delta \mathrm{Ne})\end{array}$ & $\begin{array}{c}\text { Radiogenic } \\
{ }^{4} \mathrm{He}(1 \mathrm{e}-8 \mathrm{cc} \\
\text { STP/g) }\end{array}$ & $\begin{array}{c}\text { Recharge T } \\
\left({ }^{\circ} \mathrm{C}\right)\end{array}$ & $\begin{array}{c}{ }^{{ }^{3} \mathrm{H} /{ }^{3} \mathrm{He} \text { Age }} \\
\text { (years) }\end{array}$ & $\begin{array}{c}\text { Fraction } \\
\text { Premodern } \\
(\%)\end{array}$ & $\begin{array}{c}\mathrm{N}_{2} / \mathrm{Ar} \\
\text { measured }\end{array}$ & $\begin{array}{l}\mathbf{N}_{2} / \mathbf{A r} \\
\text { initial }\end{array}$ & $\begin{array}{c}\text { Excess } \mathbf{N}_{2} \\
\text { (as mg/L } \\
\text { NO3) }\end{array}$ \\
\hline CRW-1 & $25-35$ & 106909 & $09 / 08 / 2008$ & $\begin{array}{l}\text { Inertial } \\
\text { pump }\end{array}$ & 12 & $8 \%$ & $<<2.0$ & $\begin{array}{ll}21 & 1\end{array}$ & $5 \pm 1$ & $<10 \%$ & 43 & 40 & 4 \\
\hline CRW-1D & 165-185 & 106908 & $09 / 08 / 2008$ & $\begin{array}{l}\text { Inertial } \\
\text { pump }\end{array}$ & 142 & $32 \%$ & $3.0 \pm 0.3$ & 221 & $48 \pm 2$ & Pre-1965 & 42 & 45 & $<2$ \\
\hline CRW-2 & $25-35$ & 106917 & $09 / 08 / 2008$ & $\begin{array}{l}\text { Inertial } \\
\text { pump }\end{array}$ & 37 & $12 \%$ & $<2.0$ & 251 & $9 \pm 2$ & $<10 \%$ & 43 & 41 & 4 \\
\hline CRW-2D & $150-170$ & 106916 & $09 / 08 / 2008$ & $\begin{array}{l}\text { Inertial } \\
\text { pump }\end{array}$ & 234 & $28 \%$ & $<2.0$ & 251 & $40 \pm 1$ & $43 \%$ & 75 & 44 & $<2$ \\
\hline CRW-3 & $29-39$ & 106911 & $09 / 08 / 2008$ & $\begin{array}{l}\text { Inertial } \\
\text { pump }\end{array}$ & & & & & & & 44 & & \\
\hline CRW-4 & $29-39$ & 106913 & $09 / 08 / 2008$ & $\begin{array}{l}\text { Inertial } \\
\text { pump }\end{array}$ & 13 & & $<2.0$ & bad fit & $4 \pm 1$ & $<10 \%$ & 54 & 37 & \\
\hline CRW-5 & $29-39$ & 106914 & $09 / 08 / 2008$ & $\begin{array}{l}\text { Inertial } \\
\text { pump }\end{array}$ & 35 & & $<2.0$ & bad fit & $20 \pm 3$ & $<10 \%$ & 51 & 41 & - \\
\hline MW-104 & $20-40$ & 106912 & $09 / 08 / 2008$ & $\begin{array}{l}\text { Inertial } \\
\text { pump }\end{array}$ & 13 & & $<2.0$ & bad fit & $6 \pm 1$ & $<10 \%$ & 50 & 35 & \\
\hline RFS Process Well & 175-195 & 106915 & $09 / 08 / 2008$ & Spigot & 63 & & $<2.0$ & bad fit & $27 \pm 1$ & $<10 \%$ & 59 & 36 & \\
\hline Ripon City Well 12 & $165-326$ & 106910 & $09 / 08 / 2008$ & Spigot & 81 & $13 \%$ & $2.0 \pm 0.1$ & 211 & $42 \pm 2$ & $88 \%$ & 43 & 40 & 5 \\
\hline Ripon City Well 12 & $165-326$ & 106918 & $09 / 18 / 2008$ & Spigot & 102 & $13 \%$ & $2.5 \pm 0.2$ & 211 & $41 \pm 2$ & $82 \%$ & 41 & 40 & $<2$ \\
\hline Ripon City Well 12 & $165-326$ & 106922 & $09 / 29 / 2008$ & Spigot & 117 & $12 \%$ & $4.9 \pm 0.2$ & 211 & $49 \pm 3$ & Pre-1965 & 42 & 40 & 4 \\
\hline Ripon City Well 12 & 165-195 & 106923 & $10 / 07 / 2008$ & Multi-level & 101 & $23 \%$ & $2.6 \pm 0.2$ & 231 & $40 \pm 2$ & $76 \%$ & 49 & 42 & - \\
\hline Ripon City Well 12 & $220-240$ & 106924 & $10 / 07 / 2008$ & Multi-level & 132 & $12 \%$ & $3.5 \pm 0.1$ & 231 & $53 \pm 2$ & Pre-1965 & 49 & 40 & - \\
\hline Ripon City Well 12 & $268-288$ & 106925 & $10 / 07 / 2008$ & Multi-level & 146 & $13 \%$ & $5.0 \pm 0.2$ & 211 & $52 \pm 2$ & Pre-1965 & 48 & 40 & - \\
\hline Ripon City Well 12 & 306-326 & 106926 & $10 / 07 / 2008$ & Multi-level & 134 & $26 \%$ & $7.4 \pm 0.3$ & 231 & $52 \pm 3$ & Pre-1965 & 56 & 43 & - \\
\hline Ripon City Well 12 & $165-326$ & 106927 & $10 / 08 / 2008$ & Spigot & 69 & & $3.6 \pm 0.6$ & bad fit & $41 \pm 3$ & $86 \%$ & 44 & 45 & $<2$ \\
\hline
\end{tabular}


Table 5. Comparison of contaminant source water present in City Well 12 with the calculated percentage of modern water.

\begin{tabular}{|c|c|c|c|c|c|}
\hline Mass balance & Component & $\begin{array}{c}\text { Background } \\
\text { endmember } \\
\text { (assumed) }\end{array}$ & $\begin{array}{c}\text { Source } \\
\text { endmember } \\
\text { (assumed) }\end{array}$ & $\begin{array}{c}\text { Ripon CW12 } \\
\text { groundwater } \\
\text { (measured) }\end{array}$ & $\begin{array}{c}\text { Fraction source } \\
\text { water in CW12 } \\
\text { (calculated) }\end{array}$ \\
\hline Nitrate & Nitrate (as $\mathrm{NO}_{3}^{-}$) & $\begin{array}{c}12 \mathrm{mg} / \mathrm{L} \\
(\mathrm{CRW}-1)\end{array}$ & $\begin{array}{l}1770 \mathrm{mg} / \mathrm{L} \\
(\mathrm{CRW}-4)\end{array}$ & $\begin{array}{l}55 \mathrm{mg} / \mathrm{L} \\
\text { (CW12 } \\
\text { average) }\end{array}$ & $2.5 \%$ \\
\hline $\begin{array}{l}\text { Nitrate isotopic } \\
\text { composition }\end{array}$ & $\delta^{18} \mathrm{O}-\mathrm{NO}_{3}$ & $\begin{array}{c}0.9 \% \\
\text { (Nitrification } \\
\text { - see text) }\end{array}$ & $\begin{array}{c}11 \% \\
\text { (CRW-4) }\end{array}$ & $\begin{array}{c}7 \% \\
(\mathrm{CW} 12 \\
\text { maximum) }\end{array}$ & $1 \%$ \\
\hline Tritium & Initial tritium & $\begin{array}{c}0 \mathrm{pCi} / \mathrm{L} \\
\text { (Pre-modern water) }\end{array}$ & $\begin{array}{c}\text { 270-650 pCi/L, } \\
\text { 1966-1968 } \\
\text { (Curve fit to IAEA } \\
\text { precipitation) }\end{array}$ & $\begin{array}{l}69-118 \mathrm{pCi} / \mathrm{L} \text {, } \\
\text { initial tritium } \\
\text { (calculations made } \\
\text { individually) }\end{array}$ & $\begin{array}{c}14 \% \\
\text { (average of } 3 \text { bulk } \\
\text { samplings) }\end{array}$ \\
\hline
\end{tabular}




\section{References for Analytical Methods Used in This Study}

Excess Nitrogen by Membrane Inlet Mass Spectrometry:

Kana, T. M.; Darkangelo, C.; Hunt, M. D.; Oldham, J. B.; Bennett, G. E.; Cornwell, J. C., Membrane inlet mass spectrometer for rapid high precision determination of N2, O2, and Ar in environmental water samples. Analytical Chemistry 1994, 66, 4166-4170.

Oxygen and Nitrogen isotope composition of nitrate:

Casciotti, K. L.; Sigman, D. M.; Hastings, M. G.; Bohlke, J. K.; Hilkert, A., Measurement of the oxygen isotopic composition of nitrate in seawater and freshwater using the denitrifier method. Analytical Chemistry 2002, 74, 4905-4912.

Sigman, D. M.; Casciotti, K. L.; Andreani, M.; Barford, C.; Galanter, M.; Bohlke, J. K., A bacterial method for the nitrogen isotopic analysis of nitrate in seawater and freshwater. Analytical Chemistry 2001, 73, 4145-4153.

Singleton, M.J., K.N. Woods, M.E. Conrad, D.J. DePaolo and P.E. Dresel. Tracking sources of unsaturated zone and groundwater nitrate contamination using nitrogen and oxygen stable isotopes at the Hanford Site, Washington. Environmental Science and Technology, 2005, 39(10), $3563-3570$.

Oxygen isotope composition of water:

Epstein, S.; Mayeda, T. K., Variation of O-18 content of waters from natural sources. Geochimica Cosmochimica Acta 1953, 4, 213-224.

Hydrogen isotope composition of water:

J. Morrison, T. Brockwell, T. Merren, F. Fourel, and A. M. Phillips, On-Line HighPrecision Stable Hydrogen Isotopic Analyses on Nanoliter Water Samples, Analytical Chemistry 2001, 73, 3570-3575.

Tritium/Helium-3 age dating and noble gas recharge temperature:

Ekwurzel, B. LLNL Isotope Laboratories Data Manual; Lawrence Livermore National Laboratory: 2004; UCRL-TM-203316, p 133.

Aeschbach-Hertig, W.; Peeters, F.; Beyerle, U.; Kipfer, R., Interpretation of dissolved atmospheric noble gases in natural waters. Water Resources Research 1999, 35, 2779-2792.

Ekwurzel, B.; Schlosser, P.; Smethie, W. M.; Plummer, L. N.; Busenberg, E.; Michel, R. L.; Weppernig, R.; Stute, M., Dating of shallow groundwater - comparison of the transient tracers H-3/He-3, chlorofluorocarbons, and Kr-85. Water Resources Research 1994, 30, 1693-1708. 


\section{References Cited}

Burow, K. R., Shelton, J. L., and Dubrovsky, N. M., 2008. Regional nitrate and pesticide trends in ground water in the eastern San Joaquin valley, California. Journal of Environmental Quality 37, S249-S263.

California Department of Water Resources, 2003. California's Groundwater. Bulletin 118 (Update 2003), Sacramento, CA.

Cook, P. G. and Bohlke, J. K., 2000. Determining timescales for groundwater flow and solute transport. In: Cook, P. G. and Herczeg, A. L. Eds.), Environmental Tracers in Subsurface Hydrology. Kluwer Academic Publishers, Boston.

Gossell, M. A., Nishikawa, T., Hanson, R. T., Izbicki, J. A., Tabidian, M. A., and Bertine, K., 1999. Application of flowmeter and depth-dependent water quality data for improved production well construction. Ground Water 37, 729-735.

IAEA/WMO, 2010. International Atomic Energy Agency. Global Network of Isotopes in Precipitation (GNIP) (http://wwwnaweb.iaea.org/napc/ih/IHS_resources_gnip.html).

International Atomic Energy Agency, 2010. IAEA Global Network of Isotopes in Precipitation (GNIP) (http://wwwnaweb.iaea.org/napc/ih/IHS_resources_gnip.html).

Izbicki, J. A., Christensen, A. H., Hanson, R. T., Martin, P., Crawford, S. M., and Smith, G. A., 1999. U.S. Geological Survey combined well-bore flow and depthdependent water sampler. U.S. Geological Survey Fact Sheet 196-99.

Izbicki, J. A., Christensen, A. H., Newhouse, M. V., Smith, G. A., and Hanson, R. T., 2005. Temporal changes in the vertical distribution of flow and chloride in deep wells. Ground Water 43, 531-544.

Kendall, C., 1998. Tracing nitrogen sources and cycling in catchments. In: Kendall, C. and McDonnell, J. J. Eds.), Isotope Tracers in Catchment Hydrology. Elsevier, New York.

Kendall, C. and Coplen, T. B., 2001. Distribution of oxygen-18 and deuterium in river waters across the United States. Hydrol. Process. 15, 1363-1393.

Landon, M., Jurgens, B., Katz, B., Eberts, S., Burow, K., and Crandall, C., 2009. Depthdependent sampling to identify short-circuit pathways to public-supply wells in multiple aquifer settings in the United States. Hydrogeol. J., DOI 10.1007/s10040-009-0531-2.

Mengis, M., Walther, U., Bernasconi, S. M., and Wehrli, B., 2001. Limitations of using delta O-18 for the source identification of nitrate in agricultural soils. Environmental Science \& Technology 35, 1840-1844.

Nolan, B. T. and Hitt, K. J., 2003. Nutrients in Shallow Ground Waters Beneath Relatively Undeveloped Areas in the Conterminous United States. U.S. Geological Survey Water-Resources Investigations Report 02-4289.

Nolan, B. T. and Stoner, J. D., 2000. Nutrients in groundwaters of the conterminous United States 1992-1995. Environmental Science \& Technology 34, 1156-1165.

Schlosser, P., Stute, M., Sonntag, C., and Munnich, K. O., 1989. Tritiogenic He-3 in shallow groundwater. Earth and Planetary Science Letters 94, 245-256. 
Tsang, C. u., Hufschmied, P., and Hale, F. V., 1990. Determination of Fracture Inflow Parameters With a Borehole Fluid Conductivity Logging Method. Water Resources Research 26, 562-578.

van der Schans, M. L., Harter, T., Leijnse, A., Mathews, M. C., and Meyer, R. D., 2009. Characterizing sources of nitrate leaching from an irrigated dairy farm in Merced County, California. Journal of Contaminant Hydrology 110, 9-21. 